\title{
13. The United Kingdom's record on economic and social convergence with Europe: A pre-Brexit appraisal
}

\section{Damian Grimshaw}

\section{INTRODUCTION}

With Brexit looming and the likely prospect of the United Kingdom (UK) drifting further away from economic and social convergence with Europe, it is a timely exercise to appraise the country's trajectory to date. All European Union (EU) member states face significant pressures towards convergence, although whether these signify a downwards or upwards trajectory of change depends on the starting point, the nature of convergence pressure and the specific socio-economic indicator (ILO 2016). For the UK, there are long-standing question marks concerning its capacity to keep up with the socioeconomic standards enjoyed by many of its European neighbours. In part this reflects a reluctance to transform its social model. The UK has lower welfare expenditures than in France, Germany or Sweden for example, and, equally important, has only a weak political commitment to Europe's pillar of social dialogue. However, it also reflects deep-seated problems with its economic and labour market model, especially post-crisis, evidenced by strongly financialised pressures for short-term gains, relatively low research and development (R\&D) expenditures, a model of job growth skewed towards non-standard employment resulting in problems of underemployment, poor health and well-being, and a polarising skill and wage base that generates high levels of inequality by class, gender and ethnicity (Goergen et al. 2014; Grimshaw and Rafferty 2016; OECD 2016; Perrons et al. 2016; Wahrendorf and Chandola 2016; Heyes et al. 2017).

Drawing on a range of secondary data sources, this chapter engages with two key questions addressed by this book: to what extent has the UK converged with or diverged from EU economic and social indicators; and what role has social dialogue - focusing on the resources and strategies of government, employers and trade unions - played in nudging the UK on a path towards upwards convergence? The chapter covers a selection of quantitative indicators relevant to the UK narrative and seeks to provide a qualitative (institutional) appraisal that acknowledges the strengths and weaknesses of the UK's socio-economic model. Wherever appropriate, the analysis addresses the role of social dialogue in pressing for and/or influencing change in one direction or another, as well as the broader context of EU policy coordination. The empirics of the chapter are structured into three sections: macroeconomic convergence, social convergence and labour market convergence. The chapter presents a case study of bogus forms of self-employment and concludes with a summary of the argument and relevant policy concerns. The analysis 
begins with a brief overview of debates about convergence, divergence and diversity in Europe and sets out the methods for undertaking the UK-EU comparison.

\section{CONVERGENCE, DIVERGENCE OR RECONFIGURED DIVERSITY: THE UK'S PLACE IN EUROPE}

The notion of convergence associated with the UK's place in the Europeanisation project has multiple contrasting - and potentially contradictory - dimensions or meanings, reflecting the conflictual politics, interpretations and ambitions of EU and UK policymakers. This section assesses these dimensions in order to set the backdrop for our empirical analysis.

\subsection{The Power of Free Market Convergence?}

A first - and arguably dominant - dimension of convergence concerns the parsimonious notion, associated with mainstream economic growth models, that the single market ${ }^{1}$ will promote economic convergence of EU member states' economic performance and living standards. The single market grants access to a massive regional economy of producers and consumers, common product regulations and minimal tariffs and licensing costs; in 2016, around half of all UK exports and imports were with the EU (44 per cent and 53 per cent, respectively; Emmerson et al. 2016). The idea is that the common economic pressures and opportunities associated with the single market reward more efficient systems and eliminate or incentivise improvement in less efficient systems. That is, under conditions of open competition, the UK, together with other member states, will converge towards one general, superior type of economic organisation with similar levels and rates of productivity growth (Solow 1956).

Importantly, the neoclassical economic model that underpins this interpretation assumes that superior market performance requires minimum institutional interference with market allocation. This means in practice implementing reforms at member-state level to liberalise markets and roll back state intervention in the economy - especially concerning welfare state policy, state ownership of productive resources and statutory support for collective instruments in determining working conditions (see Kitschelt et al. 1999; Hermann and Flecker 2013; Heyes and Lewis 2014). The more a country's economic performance is deemed to be drifting, the more such convergence pressures insist on the merits of fundamentalist market reforms, as witnessed in the multiple country cases under the European Commission-led Troika reform (Clauwaert and Schömann 2012).

The UK may be seen as a 'best practice' adaptor to this first type of neoliberal pressure for convergence. A critical factor in understanding how convergence pressures are translated at country level is a country's past record of market reforms and, in particular, its model of cognitive filtering or ideational mediation of convergence pressures (Hay 2010). The UK stands apart from many EU member states owing to its track record since the 1980s of relatively enthusiastic implementation of neoliberal market reforms. These include early privatisation of telecommunications, public transport and utilities, liberalisation of financial markets and a raft of labour reforms that weakened trade unions' (already diminishing) 
presence and power. In part, because the relative strength, status and organisational capacity of producer groups (employer bodies and trade unions) are low in the UK, while those of finance are high, government policy has long displayed a liberalising tendency relatively unconstrained by interests that represent the real economy (Hutton 1996). The UK has to date aligned relatively well with the types of free market convergence pressures associated with, for example, the EU's Services Directive (and associated European Court of Justice rulings) and the EU's proposed trade agreement with the United States (stalled post-Trump). Moreover, whatever the actual strength of free market convergence pressures stemming from Europe, the UK has a track record of deploying the rhetoric of neoliberal market reform as a reflexive and strategic choice in order to enact unpalatable social and economic policies (Hay and Rosamond 2002; see also Taylor-Gooby 2016).

\subsection{Soft, Social Convergence?}

A second, contrasting dimension of European convergence pressures, which is less suited to the UK's status as a liberal market economy, concerns the raft of directives designed to underpin a European Social Model for EU citizens, and bolstered in 2017 by the proposal for a European Pillar of Social Rights. ${ }^{2}$ Under the principle of subsidiarity (Schmitter 1997), implementation of EU directives in multiple areas of the economy in principle sets a common floor of standards across member states, although research suggests significant cross-national diversity in practice. ${ }^{3}$ In the field of employment, the directives (see Box 13.1) have tended to raise standards in the UK (while this has not been the case in more socially advanced EU member states), with positive outcomes for working conditions and equalities, despite UK opt outs from working-time rules and from equality rights for temporary agency workers (under the Swedish derogation).

Nevertheless, compared with macroeconomic and financial convergence pressures, the EU has granted less resources and political importance to these employment and equalities issues, applying soft coordination pressures rather than the hard sanctions that accompany fiscal policy (ILO 2016). Moreover, many important areas of employment organisation are to date not covered at EU level, including collective bargaining rights and minimum wage-fixing procedures for example, so the overall impact of EU directives on the UK's social model has been limited and contingent.

\subsection{Monetary and Fiscal Policy Convergence}

A third potential convergence pressure, membership of the Economic and Monetary Union (EMU), is not of direct relevance to the $\mathrm{UK}$ as it did not relinquish its national currency and has thus been protected from the deflationary policies of the European Central Bank. Economic and Monetary Union pressures have had especially grave effects on member states under Troika control (for Greece, see Karamessini 2014), prompting serious doubts about the eurozone's welfare-improving promise of monetary integration across diverse economies (Johnston and Regan 2016). Nevertheless, there are questions about spillover effects for the UK, especially the way in which UK policy-makers adapted the austerity fiscal policy paradigm initially constructed by the Troika (under European Commission pressures for a disciplinary neoliberalism) in the wake of the financial crisis (after Gill 1997; see also, Crouch 2017). 


\section{BOX 13.1 RELEVANT EU DIRECTIVES AND ANTICIPATED IMPACTS ON EMPLOYMENT STANDARDS}

- Informing workers of their employment conditions 91/533/EC; protects against informal employment relationships.

- Health and safety for fixed-term and temporary work 91/383/EC; ensures health standards are extended to workers with temporary contracts and gives option to member states of prohibiting their use in sectors or workplaces defined as potentially dangerous.

- Protection of young people at work 94/33/EC; outlaws child labour and provides for minimum standards for health and safety, including working time.

- Posted workers directive 96/71/EC; identifies a set of core standards of the host country that apply to workers employed by posting companies (including minimum rates of pay, working hours and paid holidays, equal treatment, and health and safety at work) but social security protections follow home country rules.

- Part-time work directive 97/81/EC; designed to eliminate discrimination against part-timers in relevant labour market and social policy (including pensions, for example).

- Fixed-term contracts directive 99/70/EC; provides stronger equality of standards between fixed-term and permanent contracts of employment with a view to combating discrimination and preventing abuse arising from employers' use of successive fixed-term employment contracts.

- Transfer of undertakings 2001/23/EC: provides protection against dismissal for reasons of transfer of work activities (for example, owing to outsourcing or acquisition) and application of collective agreements to the new employer (minimum 12 months) and terms and conditions of employment (except pensions).

- Working time directive 2003/88/EC; sets specific working time standards covering maximum hours, rest breaks and paid holidays, plus additional protections for night work and for specific occupations (for example, trainee doctors and separate directives for rail, air, road and sea transport).

- Temporary agency work directive 2008/104/EC; designed to guarantee minimum standards for temporary agency workers, as well as non-discrimination, although with flexibility for employer use also.

- Posted workers enforcement directive 2014/67/EC; strengthens the application of the posted workers directive by addressing fraud and improving information exchange between sending and receiving member states.

Source: Details from the European Commission website, accessed 23 March 2018 at http:// ec.europa.eu/social/main.jsp?catld= 706\&langld=en.

\subsection{Analysing Convergence as a Set of Complex Processes and Outcomes}

When combined, the multiple and contradictory convergence pressures associated with Europeanisation can be anticipated to have mixed effects on economic and social indicators. Moreover, they are unlikely to generate a simple, homogeneous and allencompassing process of economic and social convergence across countries. One reason is that EU pressures interact with a raft of other globalisation pressures, such as labour migration, foreign direct investment (FDI), offshoring, insertion into global production networks, diffusion of new e-platform business models and the strongly neoliberalising force of financialisation. Some EU countries, including the UK, tend to be more exposed on these measures than others (partly owing to their specialised production portfolio), therefore the weight of convergence pressures varies among countries. 
Another reason is that convergence pressures do not translate neatly into convergence of policies and outcomes. This is because of country-specificity in the interpretation of convergence pressures; in the timing, selection and enactment of policy responses; in the modes of counter-actions and policy interactions; in differentiation at sub-national level; and in outcomes as measured by standard economic and social indicators (Kitschelt et al. 1999; Almond 2017). Hay (2010) calls this a process of 'contingent convergence'. Crucially, the character of UK industrial relations, especially its weak and perforated collective worker voice and relatively uncoordinated employer interests (Grimshaw and Johnson 2018), is likely to have shaped the nature of response to convergence pressures.

Further complications of analysis concern the meaning and measurement of convergence. First, differences in starting points and pace of change mean that a country's socio-economic outcomes may move in the same direction as a European average but nevertheless still diverge over time (Hay 2000). Secondly, convergence may be better examined against two or more sets of average outcomes - associated, for example, with distinctive 'models' of organising employment, production or welfare states (for example, Lewis 1992; Whitley 1999; Hall and Soskice 2001; Amable 2003; Bosch et al. 2009; Kristensen and Lilja 2011), or with above- and below-average performing member states - rather than a single European average. The convergence question requires unpacking in order to separate out issues of input, mediation, process and outcome. Appreciation of contingent convergence brings to the fore the role of social actors in shaping change and allows for possible multiple points of convergence.

In the following analysis of UK performance, each indicator is analysed for up to 20 years, where possible. As well as an EU average for each indicator, the UK is compared against wider country patterns, in addition to (in most cases) the top and bottom performing countries in order to locate UK trends against possible convergence and divergence, upwards and downwards, evident among the 28 member states.

\section{MACROECONOMIC CONVERGENCE?}

Convergence of economic performance among member states is a central ambition of the European project. This section explores the changing position of the UK against wider European trends for two key measures: gross domestic product (GDP) per capita and, as a test of sustainability in light of the recent financial crisis, public and private levels of debt.

\subsection{Sub-par Growth in GDP per Capita in a Context of European Convergence and Divergence}

The UK ranks joint ninth in the EU28, with France, on the level of GDP per capita (US\$ purchasing power parity, PPP), below Germany, the Netherlands and the Scandinavian countries, among others. ${ }^{4}$ Over the past 20 years, UK performance on this headline economic measure has remained at a comfortable margin above the European average for the 28 current member states (see Figure 13.1), although the margin halved over the 1995-2015 period from a gap of 21 per cent to less than 10 per cent in real terms (constant prices GDP per capita). Of particular concern is that the UK's annual rate of 


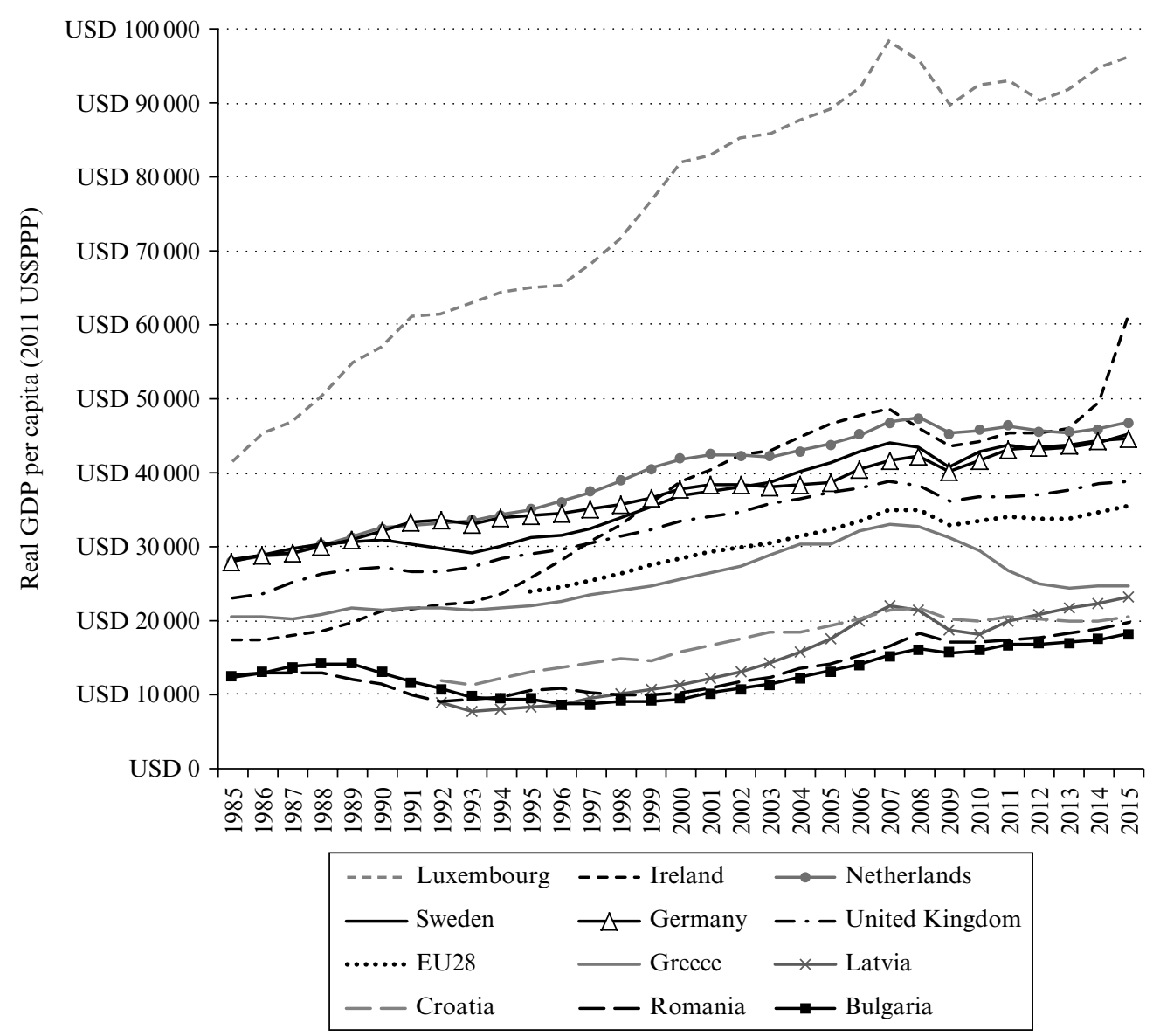

Source: International Monetary Fund World Economic Outlook (IMF WEO) database - GDP per capita current prices US\$ purchasing power parity; author's data compilation.

Figure 13.1 Trends in real GDP per capita (US\$PPP) in the UK and EU28 compared with the EU top five and bottom five performing countries, 1985-2015

growth in GDP per capita has remained below the EU average since the crisis, with a larger immediate fall and a slower return to pre-crisis performance. ${ }^{5}$ By 2015 , the level of GDP per capita in the UK was only marginally above the pre-crisis 2007 level (by 0.7 per cent), while the EU28 recorded a comfortable 2 per cent positive margin. The EU average is quickly catching up with UK standards of GDP per capita.

The question is whether the compression of UK performance towards the EU average (that is, sub-par performance) reflects a general convergence among most member states, or is peculiar to the UK? A first measure - the coefficient of variation - suggests a convergence over the period. Applied to real levels of GDP per capita across the EU28, it decreased from 0.51 in 1995 to 0.44 in 2015 . There was little change during the late 1990s and in the years since the crisis; the bulk of the narrowing of standards of living occurred 
in the five or so years running up to the economic crisis (2002-07). If we exclude the two countries with significantly higher and lower than average rates of change during the period (Ireland and Greece, respectively), then the measure suggests even more marked convergence (from 0.52 to 0.41 during 1995-2015). A second measure is the minimummaximum (min-max) range of GDP per capita. Excluding Luxembourg (since its GDP per capita is nearly twice that of the second ranked country), the min-max range changed from US\$8300-36300 in 1995 (a multiple of 4.4) to US\$18100-61 700 (a multiple of 3.4), again supporting convergence. The UK's drift towards EU average levels of GDP per capita over the past two decades appears to fit with a broader pattern of convergence among all member states.

Since the crisis of 2008-09, however, the medium-term pattern is better described as divergence. Compared with 2007 levels of GDP per capita, ten countries registered a lower level in 2015, 12 a rise, and six no significant difference. More strikingly, if countries are separated into those with above-average GDP per capita and those with below-average GDP per capita, then we find two distinct patterns (Figure 13.2). The real value of GDP per capita among poorer countries has fanned out in a relatively wide and ad hoc manner, while trends among richer countries have been funnelled within a relatively narrow range (with the notable exception of Ireland ${ }^{6}$ ). It is among the poorest countries that we find both the very high performers (Poland and Malta among others, representing a convergence/catch-up pattern of change), as well as the countries suffering the most severe collapse of living standards (Greece, Cyprus and Italy, reflecting divergence). What we observe since the crisis, therefore, is UK performance below the overall average, but on a par with its rich comparator countries and set amid a fractured pattern of both convergence and divergence of levels of growth in real GDP per capita across Europe as a whole.

\subsection{UK Debt Problems Are Worse than Average and Countries Are Diverging}

In measures of public and private debt, the UK sits at around the EU average for gross government debt, but is above average for private household debt and on both measures appears to have diverged for the worse from EU performance. Across the 28 member states, Eurostat data show that average government debt for the EU as a percentage of GDP was stable, even falling, during the pre-crisis 2000s, but then rocketed from 43 per cent in early 2008 up to a peak of 73 per cent in 2014, falling slightly to 71 per cent by mid-2017. ${ }^{7}$ By comparison, UK government debt was comfortably below the EU average until the crisis. Then, because of the enormous size of the government bailout of its financial institutions (reflecting the abundance of financial institutions in the UK economy and the loose regulations governing access to credit), debt escalated at a faster pace than the EU average, more than doubling to reach 87 per cent of GDP by mid-2017.

Across the EU, country patterns of government debt vary considerably and have diverged since the crisis (Figure 13.3): pre-crisis minimum-maximum debts ranged from below 10 per cent to a little over 100 per cent of GDP; but since the crisis the maximum range has extended considerably, with three countries exceeding 120 per cent (including Greece at a peak of almost 180 per cent of GDP). Excluding the three best and three worst performing countries, the min-max range varied from 22 per cent to 66 per cent of GDP at the end of 2002 (a 44 percentage point difference) but spread to 37 per cent to 


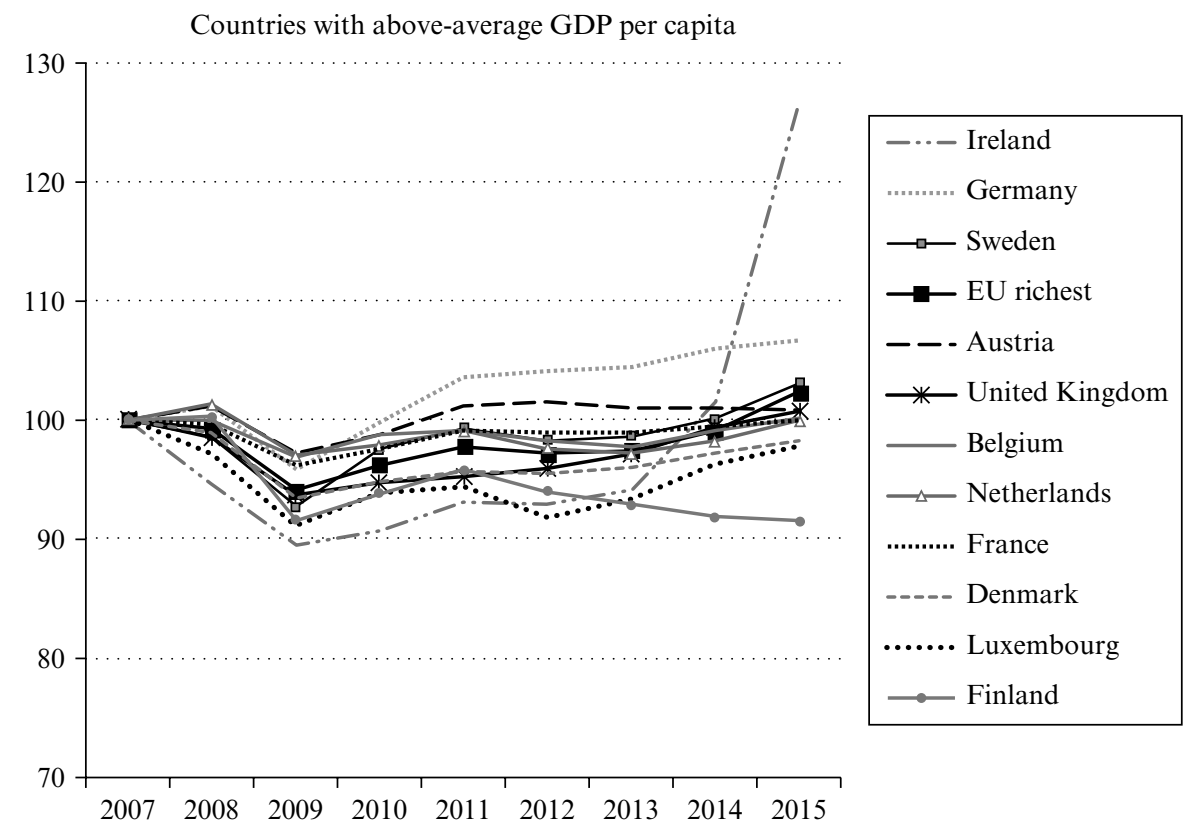

Countries with below-average GDP per capita
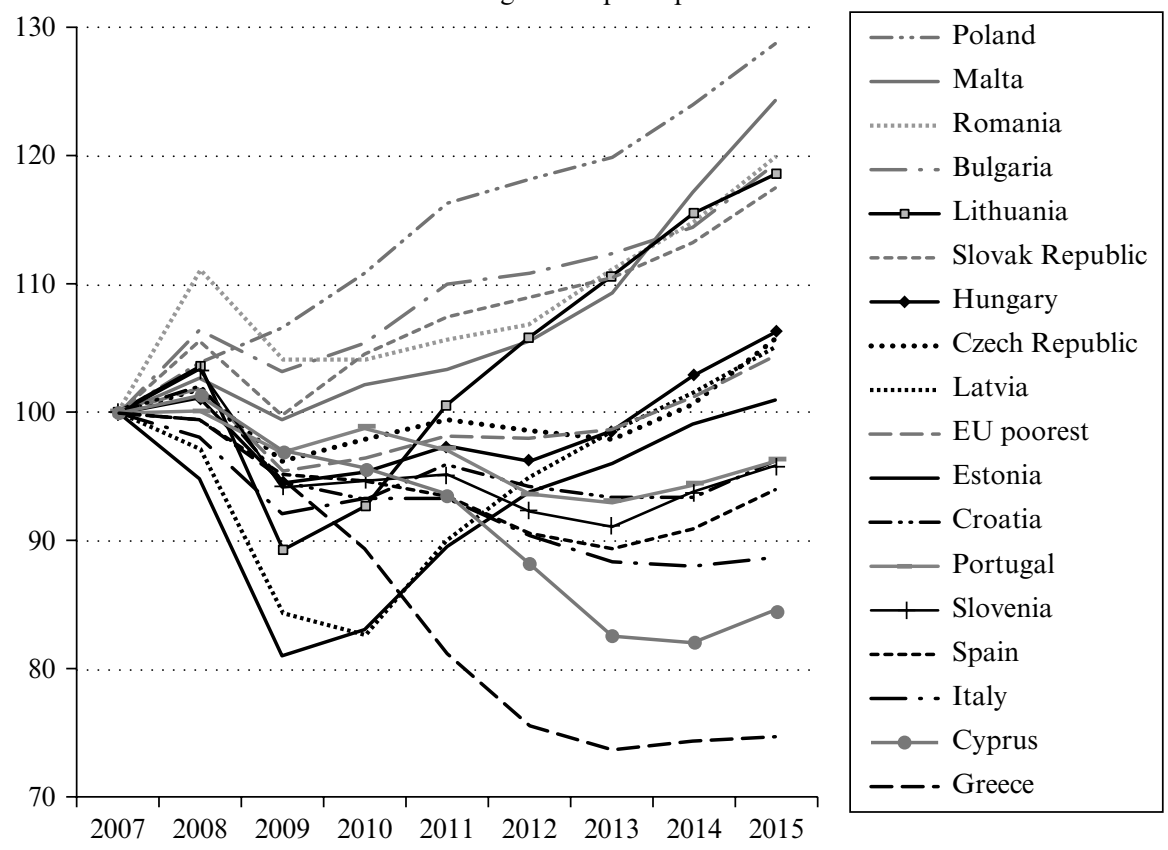

Source: IMF WEO database - GDP per capita constant prices in national currency, fixed at 100 in 2007 (Malta missing); countries ranked above and below EU28 average using 2015 data; author's compilation.

Figure 13.2 Divergent trends in real GDP per capita in the EU since the crisis, 2007-15 


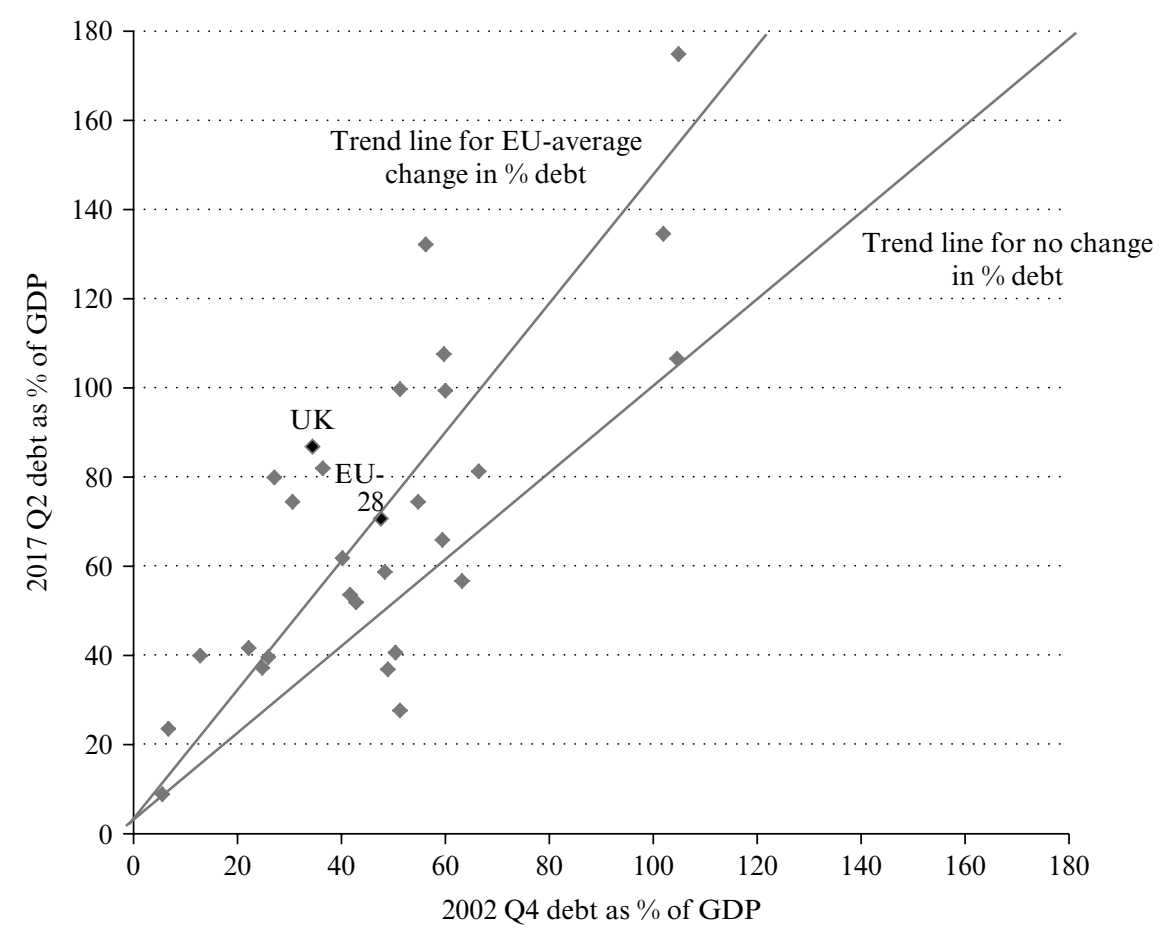

Source: Eurostat, accessed 23 March 2018 at http://ec.europa.eu/eurostat/tgm/download.do?tab=table\& plugin $=1 \&$ language $=$ en\&pcode $=$ tipsgo 20 (accessed on 8 November 2017); author's compilation .

Figure 13.3 Gross government debt as a percentage of GDP, UK and EU28, 2002-17

108 per cent by mid-2017 (a 71 point gap). Thus there has been a clear increase in government debt in Europe since the crisis, alongside a substantial divergence of performance. The UK joined another 11 countries in becoming more indebted at a greater rate than average for Europe, while four countries managed to reduce government debt as a share of GDP during this period.

The UK also experienced a massive boom in private, household debt $^{8}$ prior to the financial crisis. It is now widely realised that its consumption patterns before 2008 (and in part the resulting GDP growth) were strongly reliant on people's access to credit rather than on real wage and productivity gains. In the UK economic model, debt moved far beyond its function as an instrument for smoothing consumption spending and supporting transactions (such as home ownership) necessary for improvements over the life cycle of individuals and families. Instead, it exacerbated the risk of a financial crisis, made consumption patterns vulnerable to interest rate rises and was associated with rising numbers of repossessions of homes, homelessness and defaults on loan payments (Grimshaw 2015). As a proportion of total income, household debt was relatively stable during the 1990s at around 95-105 per cent but then ballooned from 104 per cent in 2000 to 160 per cent in 2007.

A major problem for the UK today in preparing for Brexit is that this pattern has 


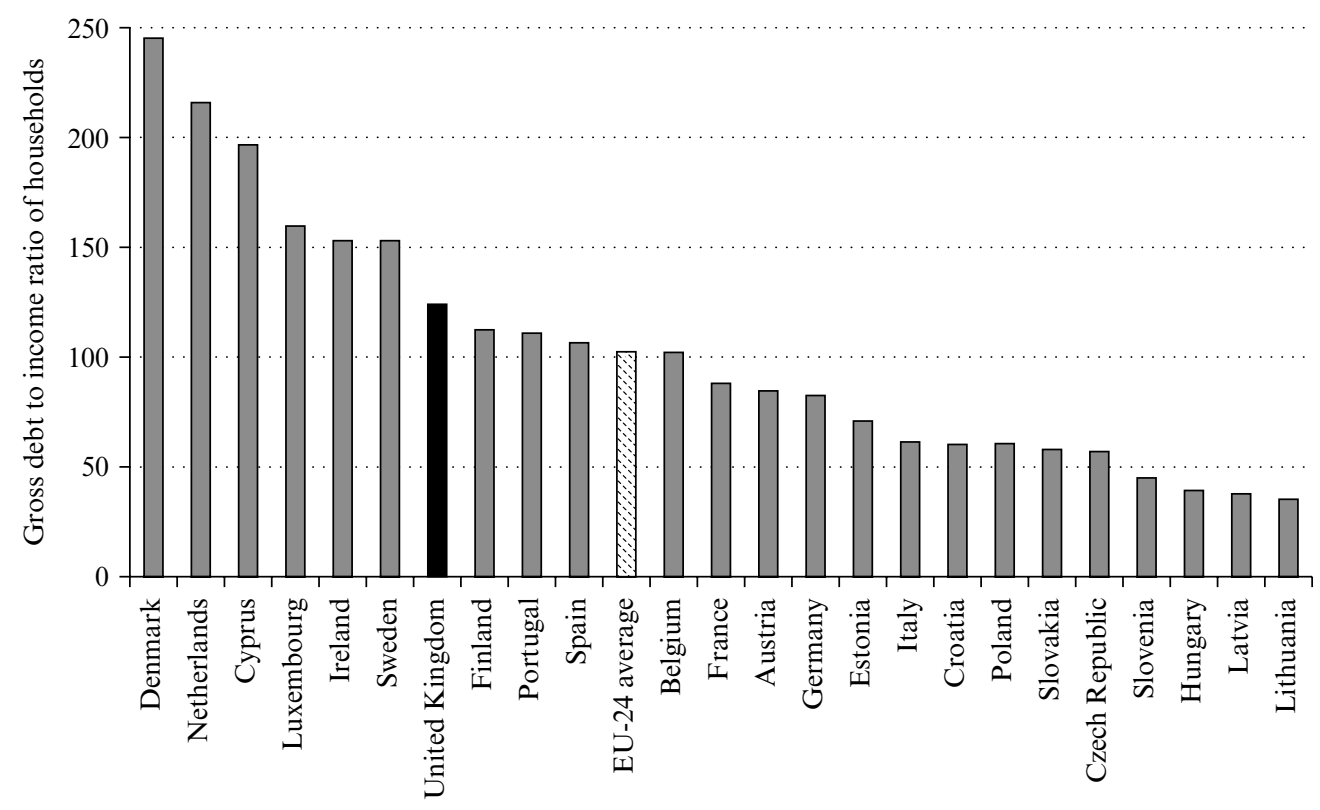

Note: Gross debt-to-income ratio of households (including Non-Profit Institutions Serving Households) is defined as loans (European System of National and Regional Accounts, ESA, 2010 code: AF4) plus liabilities divided by gross disposable income (B6G) with the latter being adjusted for the net change in pension entitlements (D8net); provisional data for Cyprus and France and 2012 data for Croatia.

Source: Eurostat data 2015; author's compilation.

Figure 13.4 Gross debt to income ratios for households in the UK compared with the $E U, 2015$

re-emerged. After the crisis, household debt fell, down to 140 per cent in 2015. However, it has subsequently started to rise again (Office for National Statistics data, in Harari 2017). Compared with Europe as a whole, UK citizens are among the most indebted, with a debt:income ratio for households of 124 per cent in 2015. This places the UK seventh among the 24 countries for which data are available and well above the EU24 average ratio of 103 per cent. The UK is below the very high levels recorded in Denmark and the Netherlands - although these two countries do not suffer a national savings problem as the UK does - but far above similarly sized economies such as France, Germany and Italy, where ratios are below 100 per cent (Figure 13.4). Among the most indebted countries, there have been mixed trends since the crisis: Denmark and Ireland experienced a fall in household debt to income up to 2015, while Cyprus and Sweden experienced a further rise. More widely, across Europe, the overall pattern has not converged, with patterns of rise and fall among the least indebted countries leading to changes in the rankings of individual countries but no obvious tendency towards the mean.

A further cause of concern in the UK is that household debt is increasingly likely to involve unsecured loans (that is, not secured against an asset) and is especially high as a proportion of income among the poorest households. While the value of mortgage debt 
increased by 10 per cent during the five-year period 2012-17, credit card debt and student loans increased by 114 per cent and 24 per cent, respectively, amounting to around onefifth of the value of mortgage debt by 2017. Also, people's anxieties about household debt are very unequally shared; households in the bottom income quintile experience private debt at a level of 83 per cent of income, while the ratio for all other income quintiles ranges between 12 and 13 per cent (ONS 2016, table $7^{9}$ ).

There appear to have been two triggers of the UK's soaring household debt, neither directly linked with Europe. The first was the 1990s deregulation of the financial services industry, which was the main catalyst for increased access to credit. The second, which sustained and exacerbated households' need to leverage consumer spending against both secured and unsecured debt was the stagnation in real wages, which fed into stagnation of household incomes from 2002. Figure 13.5 shows the impact of these two factors, first in accelerating relative levels of debt from the year 2000 as credit controls were relaxed, and then in sustaining the steep rise from 2002 up to the 2008 crash as people responded to stagnating real wage growth by using credit as an alternative source of income to sustain living standards.

Judging economic performance with the two measures of real living standards (GDP

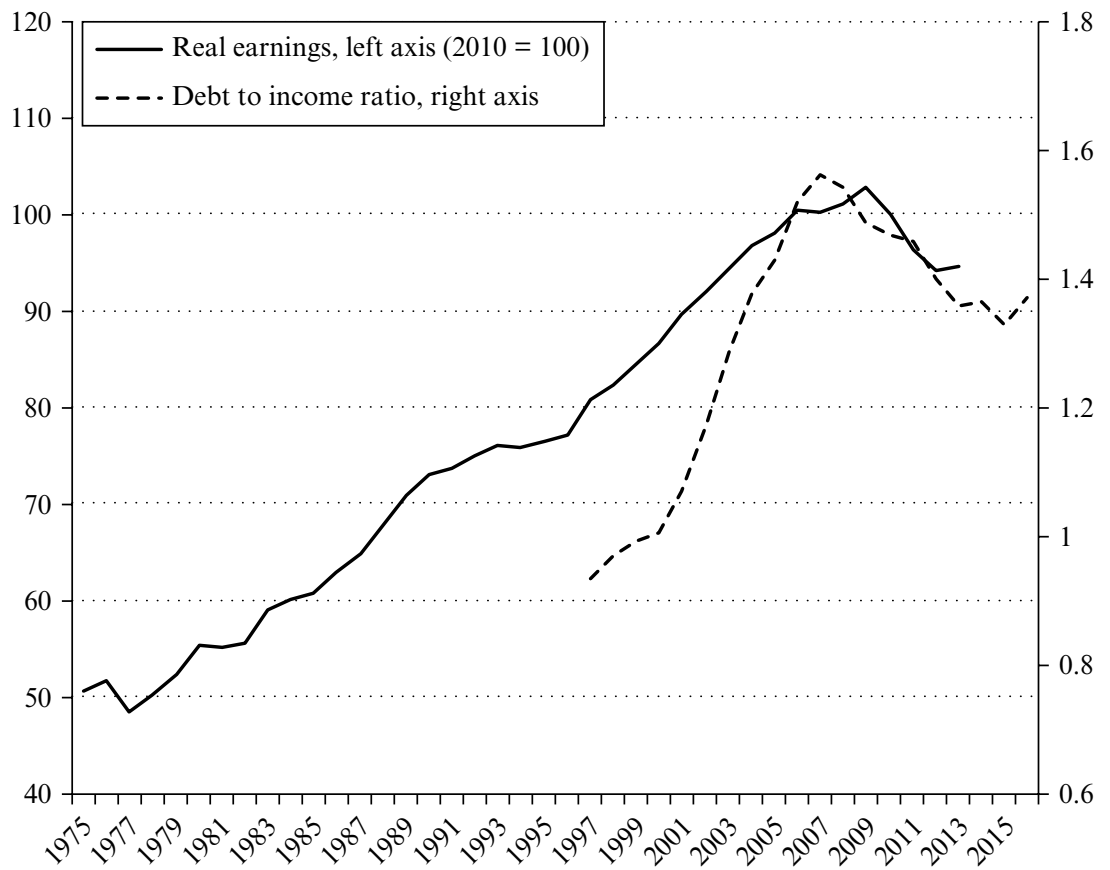

Source: Household income from Matt Whittaker (Resolution Foundation) adjusted for Consumer Price Index, after housing costs (using Department for Work and Pensions Family Resources Survey); debt to income ratio from Office of National Statistics, accessed 23 March 2018 at http://econdata.uk/finance/ household-debt/commentary-household-debt/; author's compilation.

Figure 13.5 Trends in real equivalised household income and household debt to income ratio, UK, 1975-2017 
per capita) and ability to sustain these living standards (government and private debt), the analysis suggests that the UK has performed below average for Europe. Given that the overall pattern across Europe since the crisis is one of divergence, with medium-term evidence of stagnation of living standards and rising debt, any country that performs less well than the average is cause for concern.

\section{SOCIAL CONVERGENCE}

Economic indicators are an important measure of the UK's convergence with the EU, but not the only indicators. It is also valuable to assess the wider social dimensions of European standards experienced by UK citizens, especially in light of the European project. This section assesses measures of human development, income inequality, poverty, and government expenditures associated with its welfare state functions.

\subsection{Strong Human Development Capacities Are Impaired by High Inequality}

A first, increasingly referenced, indication of a country's standard of living is its level of human development. The UK scores relatively well on the UN's composite index, ranking sixth in the EU, according to the latest 2015 data (down from fourth place in 2000). The measure is a composite of average scores on three human development indicators: a long and healthy life, knowledge and a decent standard of living. Within the EU28 range of $0.79-0.93$, the UK scored 0.91 . For the most part this 28 -country range has not diverged or converged greatly since 2000 . It has, however, shifted upwards considerably (Figure 13.6).

The downside for the UK, however, is that, unlike most other European countries, it suffers from high inequality, which means that many UK citizens do not share the experience of 'very high human development' identified by the United Nations Development Programme (UNDP). With a Gini coefficient measure of income inequality of around 0.36, Organisation for Economic Co-operation and Development (OECD) data suggest the $\mathrm{UK}$ is second most unequal in the EU, after Estonia (data missing for six of 28 member states). Inequality has diminished in recent years in the UK, as it has in two other high-inequality countries, namely, Portugal and Latvia, but there is no uniform trend, as the counter-examples of Greece, Spain and Estonia demonstrate (Figure 13.7).

\subsection{Rising Problem of Poverty among the Working-age Population}

Importantly, inequality in the UK is not a description of wide differences between the middle classes and rich households, where everyone has a minimum decent standard of living. It rather involves both a large gap between the middle- and high-income households and a very high share of households in poverty - a clear indication that the United Nations' measure of 'very high human development' is not enjoyed by a large minority of the UK's citizens. This is not a new situation. The rise in poverty occurred in the 1980s (Cribb et al. 2017) during a period of deregulatory reforms under the Thatcher government, poor labour market performance and the 'rolling back' of the state, particularly concerning welfare state transfers. While around one in seven households were poor in 


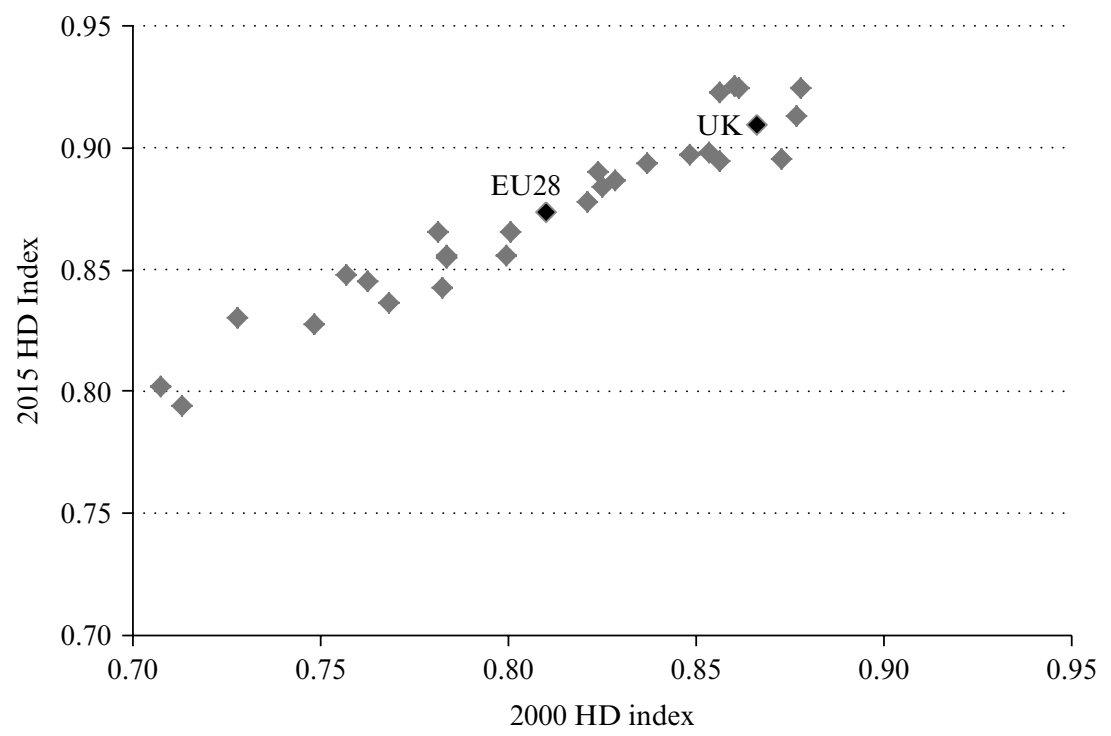

Source: United Nations Development Programme, accessed 23 March 2018 at http://hdr.undp.org/en/ composite/trends; author's compilation.

Figure 13.6 Changes in the Human Development Index for the UK and EU28, 2000-2015

the 1970s, by the early 1990s this had expanded to one in four households. The more recent pre- and post-crisis trends suggest this high level has become intractable, with only a slight reduction to 22-23 per cent during 2008-15 (Figure 13.8). Furthermore, a radical change in the character of poverty has occurred in the past two decades, as the cause of poverty among working-age households has shifted from unemployment to low and irregular wages: while in 1995-96 less than half of people in poverty (45 per cent) belonged to a working household, by 2015-16 this had risen to two-thirds (66 per cent) (Cribb et al. $2017^{10}$ ).

Relative to the rest of Europe, the UK sits in a middle group of countries with an approximately average share of people in poverty (16 per cent UK versus 17 per cent EU average) (Figure 13.9). Given the wealthier status of the UK, we might expect it to have a lower level of poverty. Other comparably wealthy member states have been able to successfully minimise the experience of poverty (for example, Finland, Denmark and the Netherlands), but the UK joins those in which relative rates of poverty in 2016 were still relatively high (Table 13.1).

Trend data for Europe since the crisis suggest that the bulk of member states have experienced a rise in relative poverty since 2008, which has been considerable in several countries, such as Slovenia, Hungary and (surprisingly) Sweden. The UK's recorded decline in relative poverty (according to both Eurostat data and national data for this period) is notable and only matched by Finland, and to a lesser extent Austria, among wealthy countries (Figure 13.10).

However, the overall decline in poverty in the UK is the result of contrasting trends for 


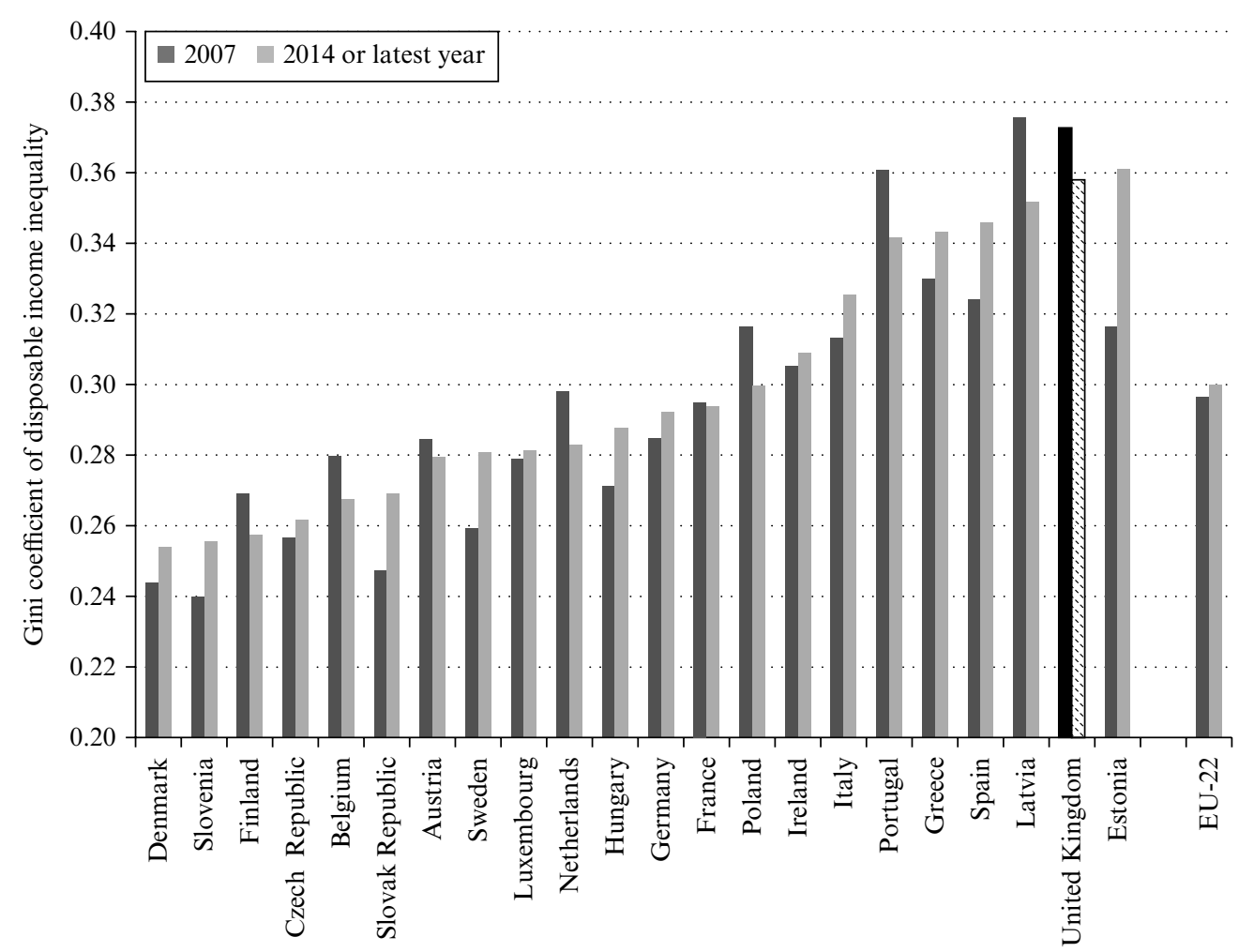

Source: OECD income distribution database.

Figure 13.7 Gini coefficient of disposable income inequality, 2007-14

different people. On the one hand, there has been a significant fall since the late 1980s in rates of poverty among pensioners, thanks in recent years to a 'triple-lock' arrangement, which secures annual rises in the real value of pensions. On the other hand, people of working age, and especially those in paid employment, have experienced a rise in poverty (see Figure 13.9). There are considerable concerns that the post-2010 cuts in welfare expenditures have already impacted adversely on rates of poverty among children and will continue in the wrong direction for several more years unless the policy is halted; one estimate suggests that between 2015-16 and 2021-22 child poverty will increase by a further four percentage points, with three of the four-point increase (some 400000 children) attributable to welfare benefit changes, especially the 2015-20 freeze in the nominal level of benefits and cuts to child benefits (Hood and Waters 2017). ${ }^{11}$

\subsection{Rolling Back the Welfare State}

A further measure of social convergence is related to the direction of travel across Europe with regard to countries' willingness to develop and enrich their welfare states especially the quality of schooling, health care and income security for the sick, disabled, 


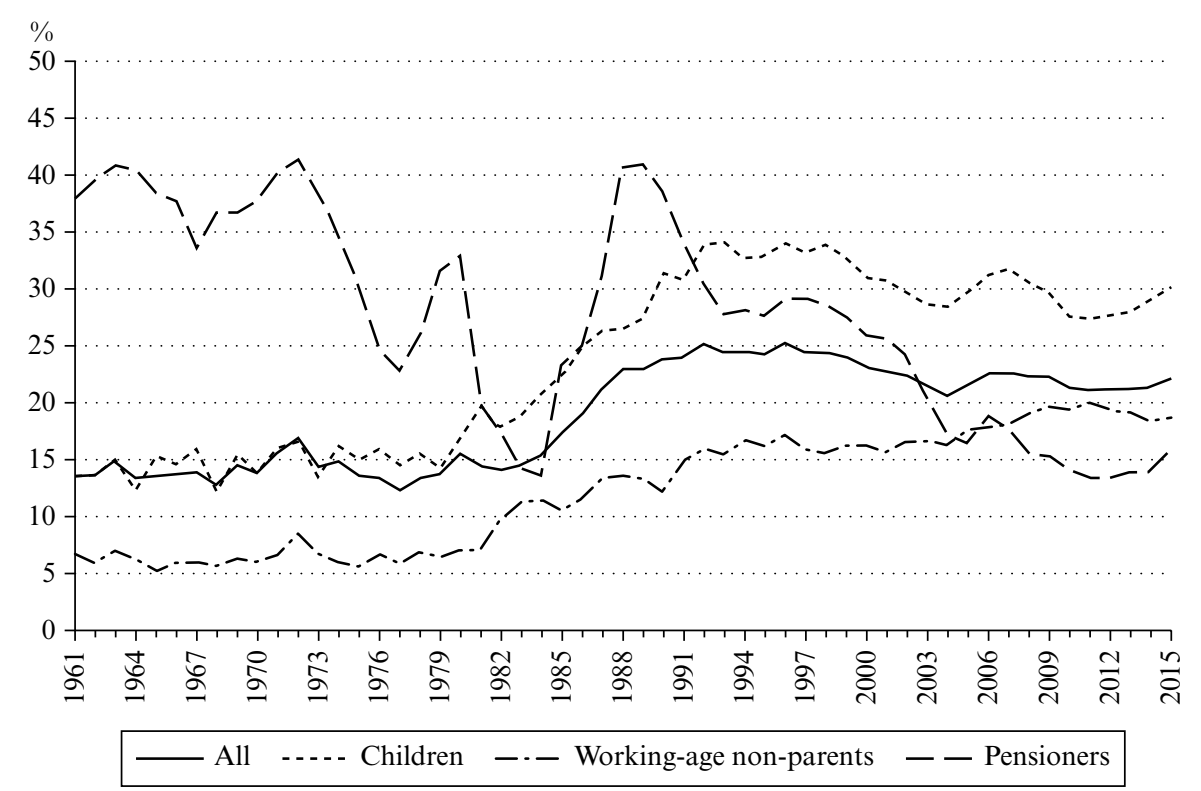

Source: Adapted from Cribb et al. (2017, fig. 4.5), which uses data from the Family Expenditures Survey and Family Resources Survey.

Figure 13.8 Trends in relative poverty (after housing costs), UK, 1961-2015

unemployed, poor and retired. Given the different regulatory and cultural approaches to the design, development and administration of welfare states across Europe - reflecting gender relations, market pressures of commodification and industrial relations traditions (Esping-Andersen 1990; Lewis 1992; Stier et al. 2001; Vaughan-Whitehead 2013) - it is a complex task to assess the extent to which this dimension of social life is converging or diverging. This section presents a snapshot of patterns and trends by comparing categories of government expenditures.

Compared with an average 45 per cent share of government expenditures in GDP in Europe, the UK falls below with 42 per cent recorded in 2016 (OECD data). ${ }^{12}$ This is considerably below that of the statist regime of France (57 per cent of GDP) and the advanced social democratic welfare states of Scandinavian countries (50-56 per cent), but in line with Spain, Poland and Slovakia (41-2 per cent). The trend in Europe since the crisis has been downwards (from 50 per cent in 2009), with no obvious sign of convergence, ${ }^{13}$ although in most countries - including the UK - OECD data suggest that the level of government expenditures in 2016 is still higher than the pre-crisis 2007 level of government spending. In terms of the three major areas of welfare state spending - education, health and social protection - there is a wide variety among European member states, reflecting both differences in government commitment to its welfare function and variation in the mix of public and private provision. The UK is above the EU average on health spending and close to average on education and social protection spending (Figure 13.11). 


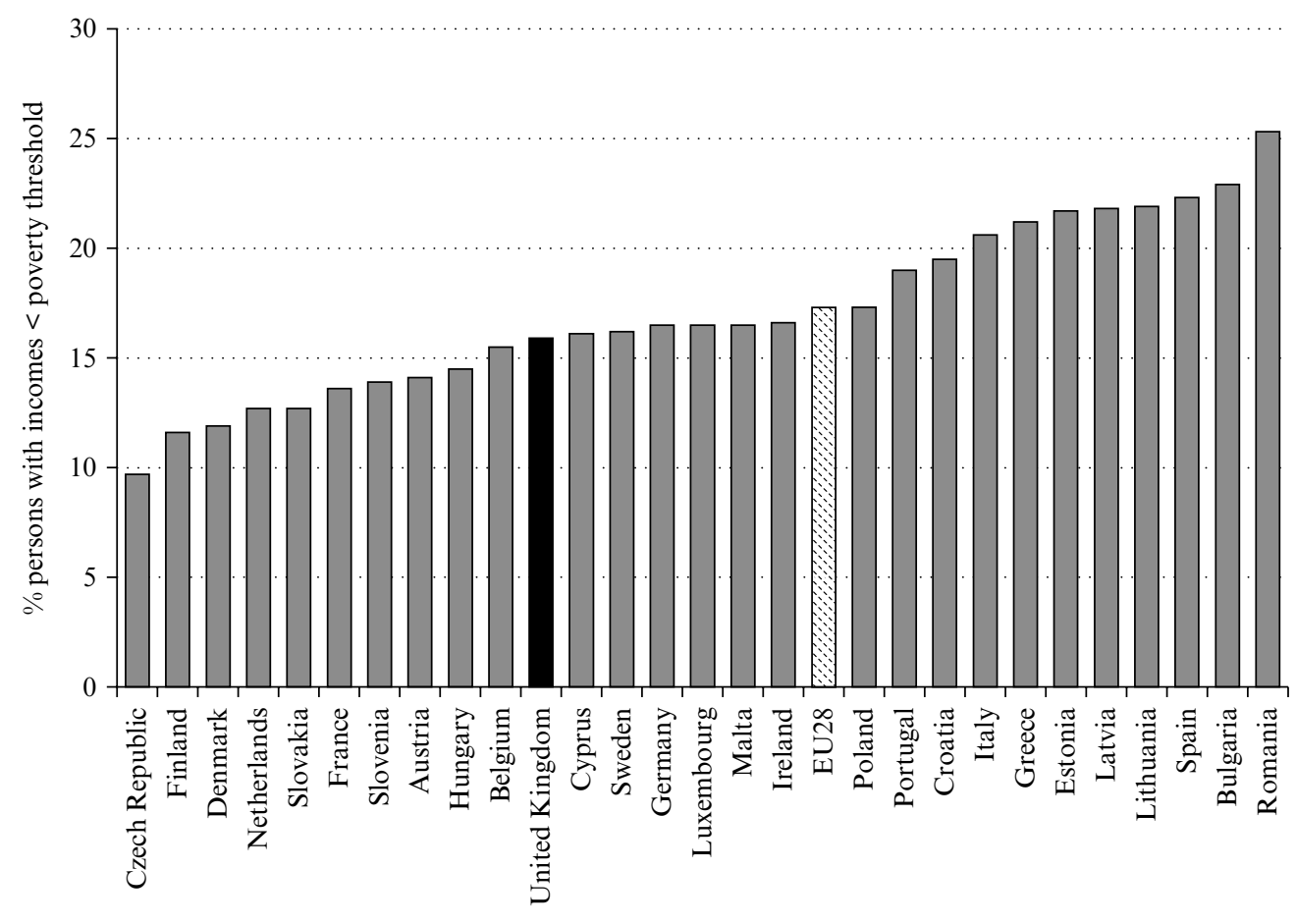

Source: Eurostat data, code t2020_52.

\section{Figure 13.9 People at risk of poverty after social transfers, UK, 2016}

More detailed national data ${ }^{14}$ demonstrate that UK spending in these three areas has been cut since 2010, less as the result of a post-crisis response than an ideological shift in government policy (Taylor-Gooby 2016) which has sought to recast the British welfare state as a residual service to citizens, contrary to the ambitions of many for high-quality universal services, once epitomised by the promise of the National Health Service. Total government spending has been cut radically from 46 per cent of GDP in 2009-10 to 39 per cent in 2016-17. Trends in real-terms spending per capita in the three key functions reflect the post-2010 Conservative-led governments' determination to roll back welfare state activities (Figure 13.12) and a failure of the social partners (public sector employers and trade unions) to prevent the cuts: education spending has been cut by 17 per cent since its 2010-11 peak, social protection spending by 5 per cent since its 2012-13 peak and health spending has slowed to less than 1 per cent growth per year on average.

In each area, the main employer bodies, trade unions, independent think-tanks and civil society organisations have led public protests, campaigns, media briefings and political lobbying in an effort to reinstate a sense of public duty among government ministers. For example, in education, the General Secretary of the National Association of Head Teachers has made spending cuts one of its three priority campaigns and repeatedly lobbies government over its radical downsizing of expenditures, for it to 'stop seeing education as a cost and instead see it as an investment in the future' ${ }^{15}$ School management 
Table 13.1 Comparing country wealth (GDP per capita) with the share of persons in relative poverty, United Kingdom

\begin{tabular}{|c|c|c|c|c|}
\hline & & \multicolumn{3}{|c|}{$\begin{array}{l}\text { Percentage of persons in poverty (below } 60 \% \text { of median } \\
\text { income) }\end{array}$} \\
\hline & & $\begin{array}{l}\text { Medium } \\
10-14 \%\end{array}$ & $\begin{array}{l}\text { High } \\
15-19 \%\end{array}$ & $\begin{array}{l}\text { Very high } \\
20 \%+\end{array}$ \\
\hline \multirow{3}{*}{$\begin{array}{l}\text { National } \\
\text { wealth } \\
\text { (GDP per } \\
\text { capita) }\end{array}$} & Poor $(\$ 19000-27000)$ & Hungary & Poland, Croatia & $\begin{array}{l}\text { Greece, Latvia, } \\
\text { Romania, } \\
\text { Bulgaria }\end{array}$ \\
\hline & Average ( $\$ 28000-39000)$ & $\begin{array}{l}\text { Czech Republic, } \\
\text { Slovenia, } \\
\text { Slovakia }\end{array}$ & $\begin{array}{l}\text { Malta, Cyprus, } \\
\text { Portugal }\end{array}$ & $\begin{array}{l}\text { Italy, Spain, } \\
\text { Lithuania, } \\
\text { Estonia }\end{array}$ \\
\hline & Rich $(\$ 40000+)$ & $\begin{array}{l}\text { Netherlands, } \\
\text { Denmark, } \\
\text { Austria, } \\
\text { France, } \\
\text { Finland }\end{array}$ & $\begin{array}{l}\text { Luxembourg, } \\
\text { Ireland, } \\
\text { Sweden, } \\
\text { Germany, } \\
\text { Belgium, } \\
\text { United } \\
\text { Kingdom }\end{array}$ & \\
\hline
\end{tabular}

Source: Data extracted from Figures 13.1 and 13.9.

has joined teachers' unions in protesting against the $£ 24$ billion of cuts since 2010-11 (from $£ 111$ billion to $£ 87$ billion in $2016-17^{16}$ ). Unions have succeeded in strengthening information awareness among the public, in particular through the excellent 'schoolcuts. org.uk' website, a collective effort of the main trade unions, which enables parents and teachers to easily access information for their specific primary or secondary school about cuts in spending per pupil and numbers of teaching staff. ${ }^{17}$ However, despite the efforts and the shared management and trade union opposition to government cuts, independent analysis of Treasury objectives forecast a continued decline in real spending per pupil up to 2020 at primary, secondary and, especially, further education levels (Belfield et al. 2017). It appears the government has fixed its course, ignores dialogue with both sides of the industry, and is likely to fall down the European (and international) rankings of countries that invest in education for the future.

\section{LABOUR MARKET CONVERGENCE}

European labour markets are institutional constructs that perform in a variety of ways according to very different rules of the game (Freeman 1994). While some perform well on measures of employment participation, others focus on skill development, fulfilment at work or gender equality for working parents; these dimensions are not mutually exclusive, in that varied country bundles prevail. Any comparison of labour market characteristics or performance outcomes cannot hope to capture the spirit of differences or similarities using a narrow set of quantitative descriptors alone. This is especially relevant 


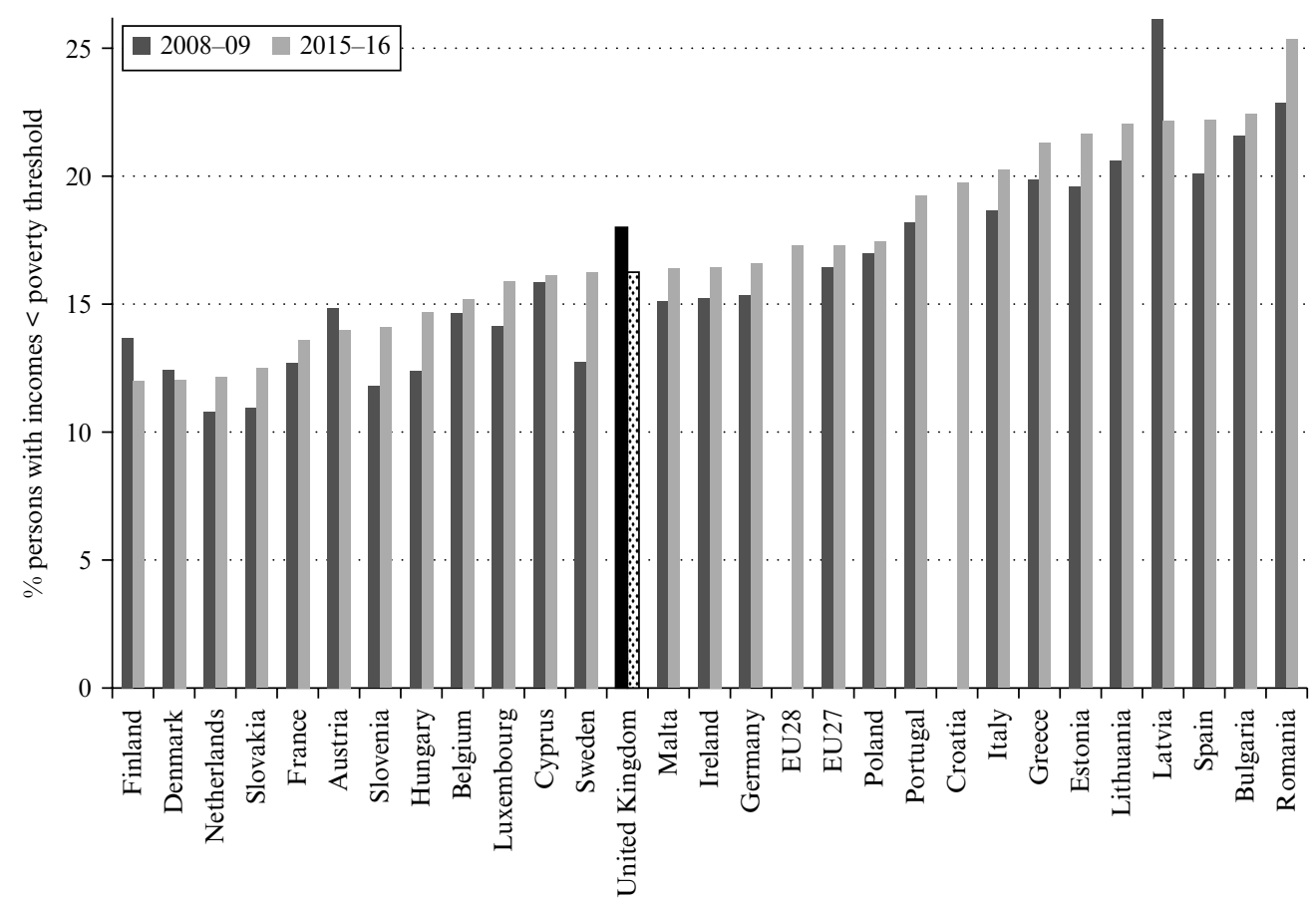

Note: Data for 2008-09 and 2015-16 are averages for two years.

Source: Eurostat data, code t2020_52.

Figure 13.10 Trends in relative poverty, UK and EU28, 2008-2009 to 2015-2016

to the UK case since it has pioneered a 'work first' approach in Europe by maximising rates of participation in employment (among men and women) and keeping the official unemployment rate down. However, this model of performance has arguably been at the cost of many indicators of decent work, not least its high incidence of low-wage work, a high share of people with irregular earnings and/or having to take non-standard forms of employment while queuing for a full-time or permanent job, and an erosion of steady improvements over the life course as opportunities for young people fall short and the social settlement for core workers (especially concerning wage rises, health-care services and promised pensions) deteriorates. This section considers a selection of these issues, in each case assessing the character of UK trends against a backdrop of convergence/ divergence in Europe.

\subsection{Record High UK Employment Rate amid European Upwards Convergence for Women}

Trends in employment participation in Europe are largely driven by what happens to women's employment (Rubery et al. 1998). First, while the EU average male employment rate has remained constant at 76-78 per cent over the past two decades, the female 

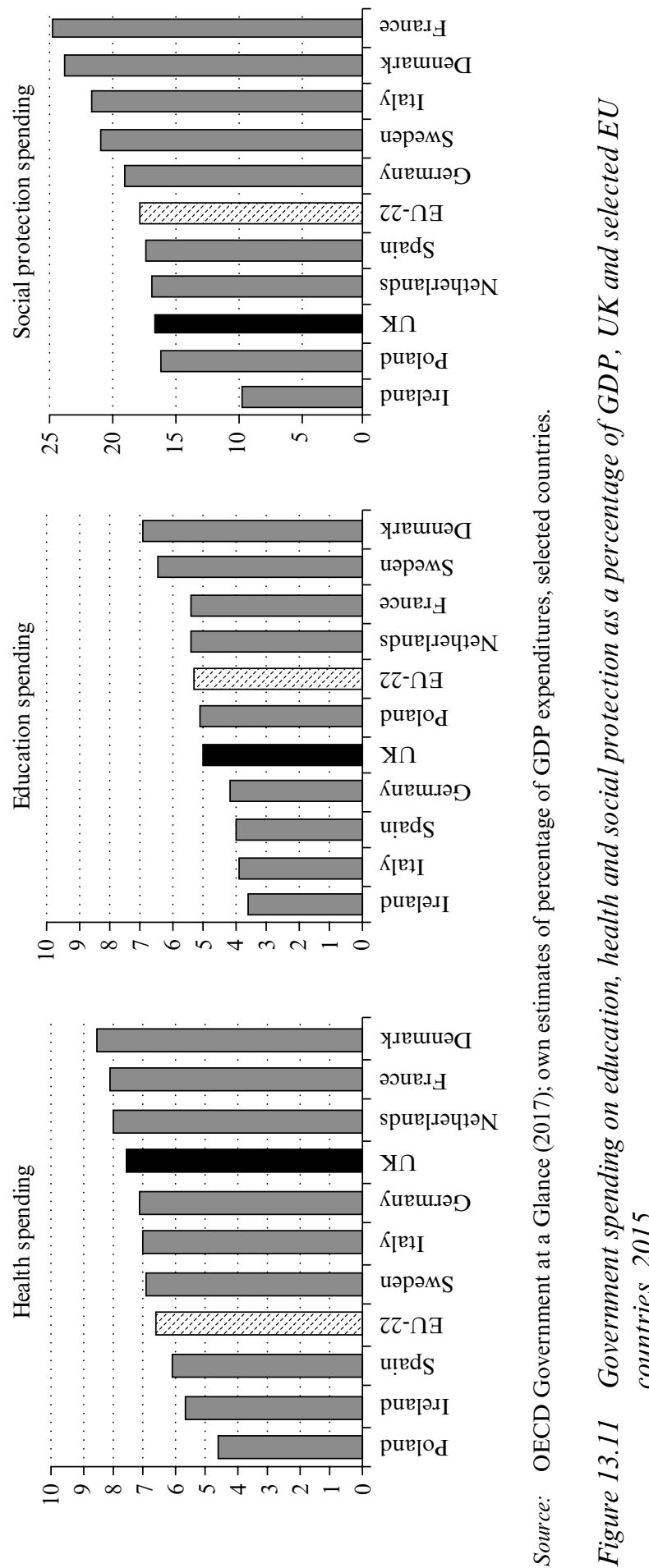


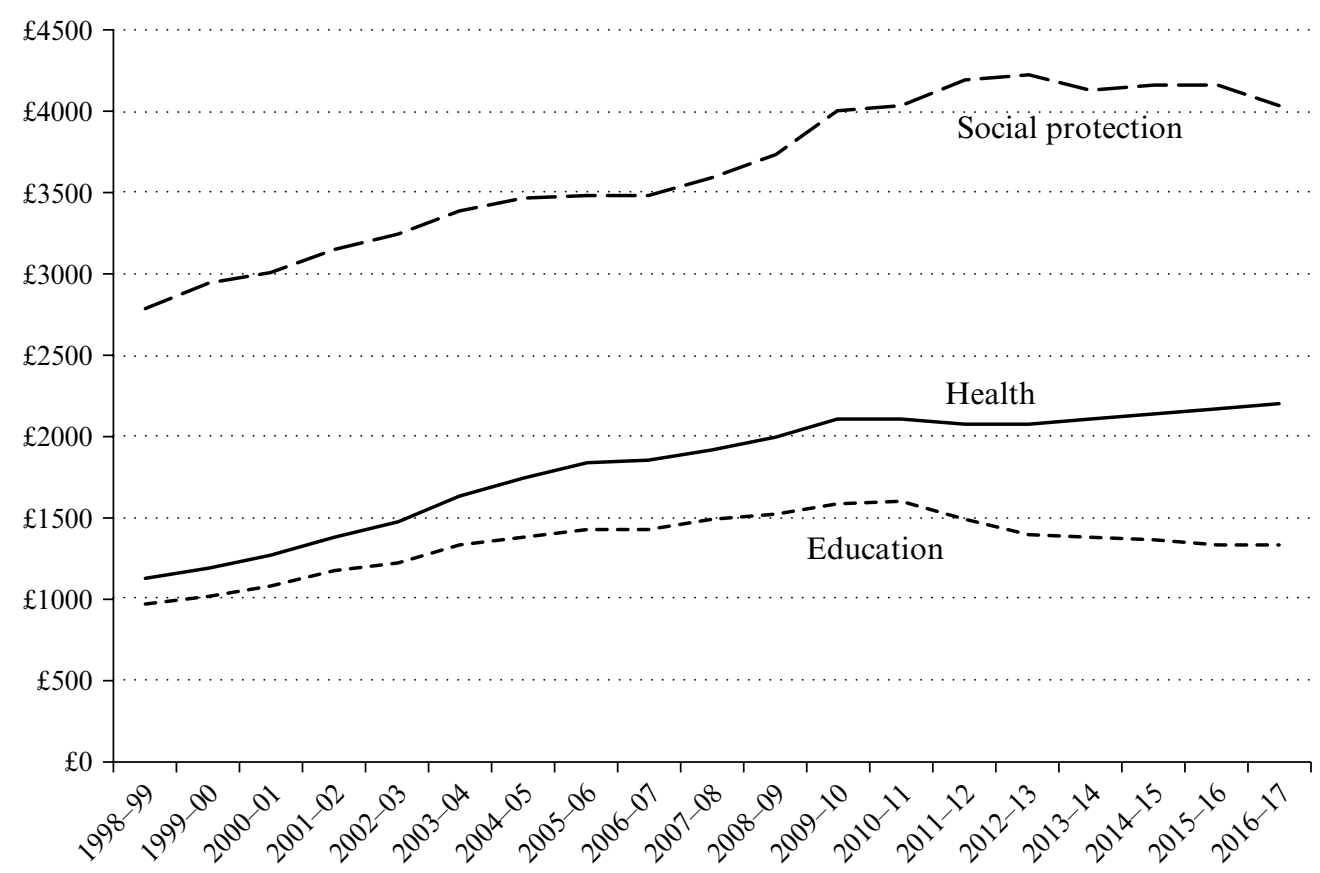

Source: HM Treasury Statistical Bulletin for real terms public expenditures and Office of National Statistics for population data; author's compilation.

Figure 13.12 Public spending by function in real terms per capita, UK, 1998-2017

employment rate has steadily increased from 58 per cent to 65 per cent (Eurostat data, 2001-17). ${ }^{18}$ It is thus women's employment rate that has driven the aggregate upwards trend (from 67 to 71 per cent over this period). Second, the variety of employment rates across Europe is far greater among women than among men, such that patterns of convergence or divergence are again largely shaped by what has happened to female employment. In 2016, the min-max range of male employment rates across EU member states was 66-85 per cent (a 19 point range), while for women it was 47-79 per cent (a 32 point range) (20-64-year-old population). In the coefficient of variation, as Figure 13.13 shows, there was a substantial reduction in the variation of female employment rates across Europe (the coefficient of variation fell from 0.16 to 0.11 during 2001-16) and a quite different pattern of narrowing, then widening, then slight narrowing among male employment rates (overall a small drop from 0.09 to 0.07 ). Again, trends in female employment rates have driven overall convergence.

In common with European trends, UK male and female employment rates increased up to the crisis, fell back (especially for men), then climbed again. In 2016 the UK ranked third and sixth for male and female employment rates, respectively. The UK has made some progress in closing the gender gap in employment rates (from 14 to 11 points over the period), but the gap remains wide compared with other high performing countries, such as Sweden (four points) and Denmark (seven points). Thus the UK has made some 

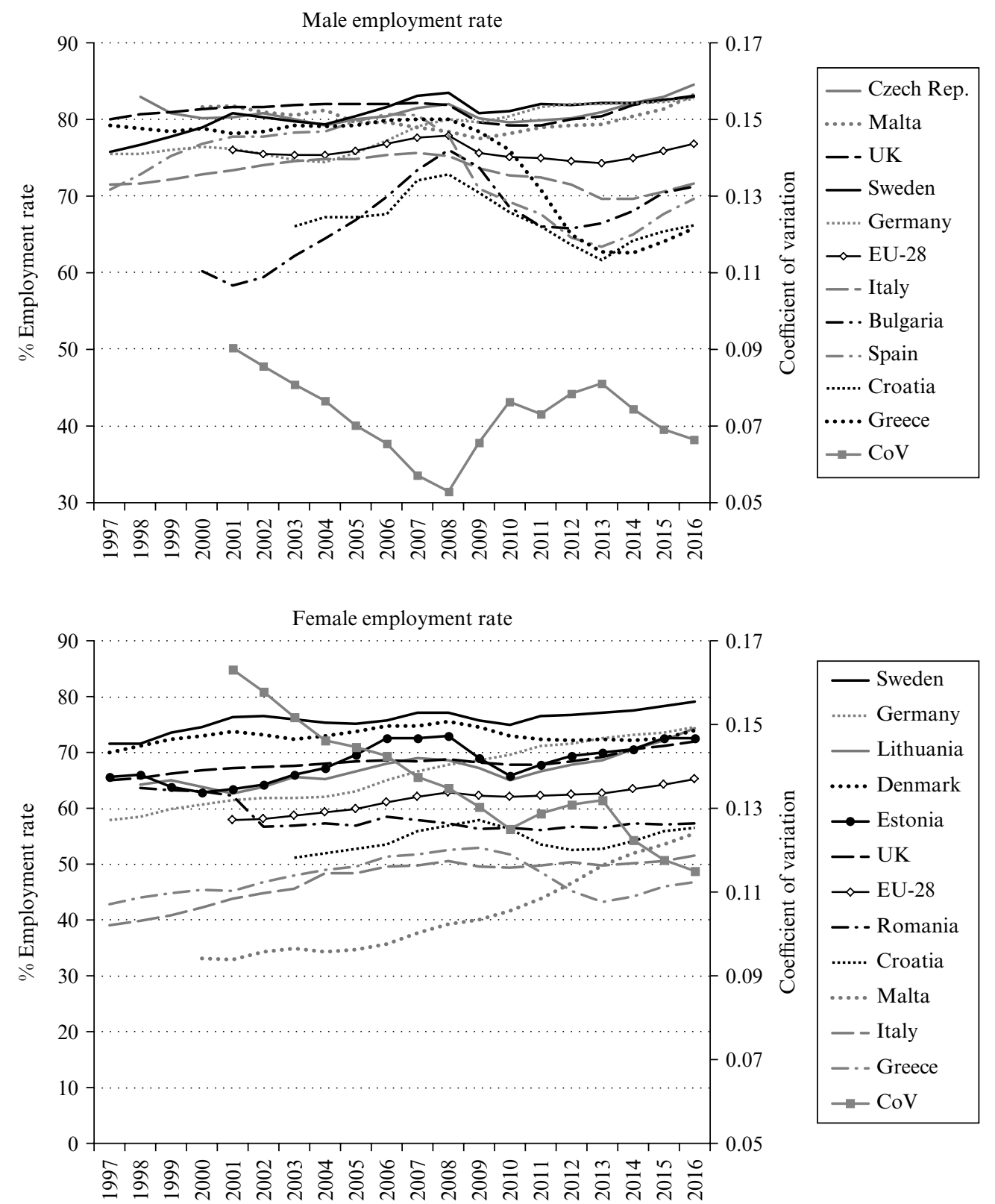

Notes: Population 20-64 years old, resident population (Labour Force Survey concept); Headcount employment measure; data for France (included in EU28) only for 2014-16.

Source: Eurostat; author's compilation.

Figure 13.13 Male and female employment rates in the UK and Europe (top five and bottom five) and the coefficient of variation, 1997-2016 
progress, but it is a long way from a gender-equal performance on headcount employment rates. This is a problem for social justice but also has substantial economic costs (see Bettio and Sansonetti 2015; Bisello and Mascherini 2017). Moreover, if we were to account for the high share of women in part-time employment in the UK and rank countries by full-time equivalent employment, the UK would fall down the rankings considerably.

In addition to its relatively high employment rates, the UK has successfully reduced unemployment since the crisis, recording the fourth lowest rate in Europe in 2017. It also has one of the lowest shares of unemployed persons in long-term unemployment (ranked third, after Sweden and Denmark). ${ }^{19}$ It can thus justifiably claim to have a dynamic labour market that is effective at generating jobs. The downside, as is now widely recognised among diverse groups representing the interests of employers, trade unions and citizens, is that UK dynamism is spurred by a specific form of labour market flexibility that does not safeguard people's right to decent employment standards and exposes a growing share of workers to low pay, gender inequity, limited access to employment rights and poor family support. There is also a strong business case against this peculiarly British form of labour market flexibility. The evidence suggests it hampers innovation in new business processes and products, disincentivises business investment in skill development, and under-utilises talent among the many educated and experienced workers trapped in irregular and insecure forms of employment; the net result is a major drag on long-term productivity growth (for example, Zhou et al. 2011; Rubery et al. 2016).

\subsection{High Shares of Low-wage Work Penalise Women}

The UK has a reputation for a high incidence of low-wage work and this is confirmed by data that rank the country in the top ten EU member states in this respect. What is less widely appreciated is that the UK's reputation is caused by the very high incidence of low pay among female employees. As Figure 13.14 shows, drawing on European Structure of Earnings Survey data, the UK is in the middle group of countries for men (ranked thirteenth), but ranks among the highest for women, with more than one in four women workers low paid (27 per cent) (ranked fourth in 2014, after Estonia, Germany and Latvia). Thus, while the risk of low pay is higher for women than for men in almost all EU countries (except Bulgaria and Romania in 2014), it is particularly high in the UK; women face almost double the risk in the UK (a ratio of 1.7).

For the direction of travel, European earnings data for the period 2006-14 show that the share of low-wage work in the UK has declined slightly for women and increased for men. This is in line with the general pattern in Europe, suggesting a problem of meeting gender equality by levelling down rather than levelling up conditions for male and female employees. The UK trend is in part the result of two changes that push in different directions and affect wage opportunities for workers in different segments of the labour market in different ways.

First, the statutory national minimum wage has been increased relative to median earnings, thus raising the lowest threshold of low wages. Organisation for Economic Co-operation and Development harmonised data record the UK as experiencing the sixth highest minimum wage rise during 2000-2016 (median earnings, data for 18 countries). Nevertheless, because it had been quite low in the years following its introduction in 1999 , 

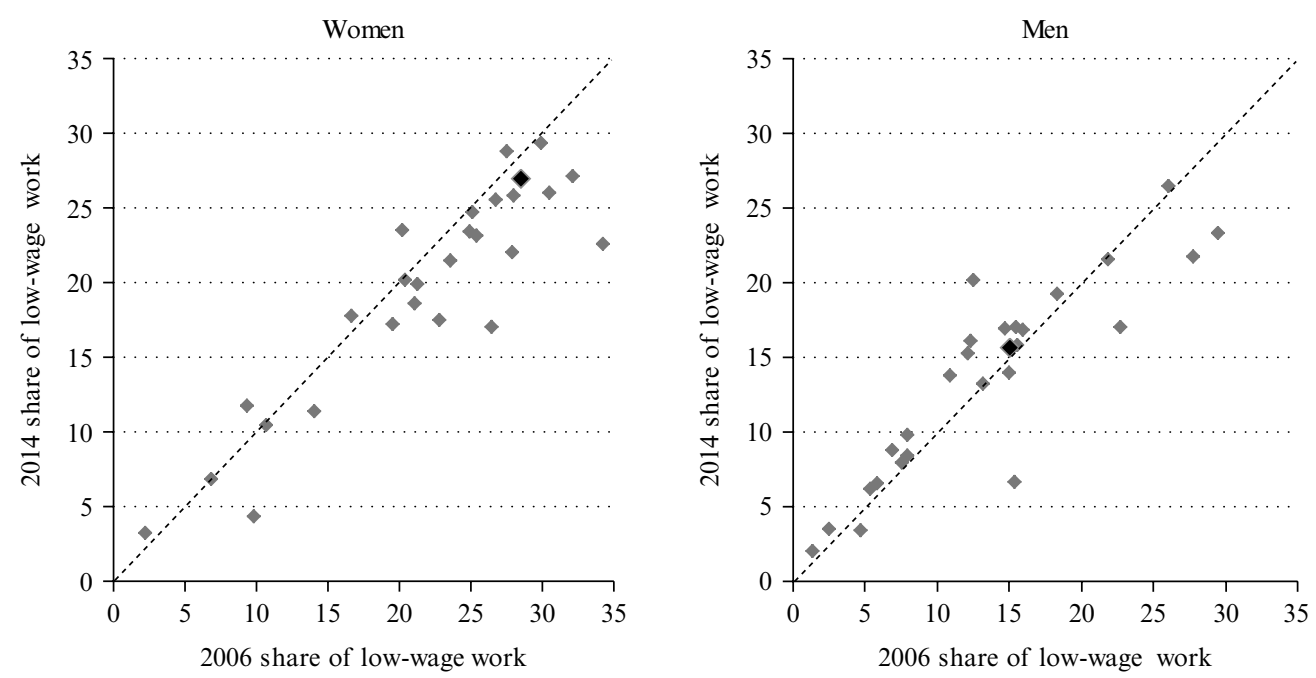

Source: Eurostat Structure of Earnings Survey, Low-wage earners as a proportion of all employees (excluding apprentices) by sex [earn_ses_pub1s], defined as wages less than two-thirds of median earnings, limited to organisations with ten or more employees.

Figure 13.14 Trends in low-wage work in the UK and Europe, 2006-14

it sits around the middle of the set of country minimum wages relative to the median; the OECD records a level of 49 per cent of adult full-earnings in the UK for 2016, compared with the highest levels of 61 per cent in France and 59 per cent in Slovenia and the lowest levels of 37 per cent in Spain and 40 per cent in the Czech Republic. Arguably, however, the UK situation is overestimated, as its adult rate (since April 2016) applies only to workers aged 25 years or over, while most EU countries set the minimum adult age at 18 or 21. The three youth rates in the UK are lower - in 2017, 54 per cent (under 18 years of age), 78 per cent (18-21 years of age) and 94 per cent (22-24 years of age) of the adult rate - reflecting an official rationale that this compensates employers for young workers' lower productivity, allows employers to invest in training and guards against unemployment. The decision to set the minimum age at 25 was also political, or institutional, as this is the threshold for differences in entitlements to student support and working tax credits. Academic and trade union studies have questioned the rationale. The evidence, moreover, suggests that most employers ignore this new age band: nine out of ten retail employees aged 21-24 years are paid the adult rate as are three out of four hospitality employees (NPI 2017). For those that use the age bands, there is a risk that pay differentials reinforce managers' expectations of productivity, so that young workers feel underpaid for their skills and capabilities, leading to retention problems (UKCES 2012).

Second, a widely observed pattern of (upwardly skewed) job polarisation in the UK (most recently analysed for 1979-2012 in Salvatori 2018) has fostered a continued demand for jobs ranked at the bottom of the occupational skill distribution. While trade and technology explanations are relevant, the UK situation is not helped by a systemic failure to institutionalise vocational qualifications in order to provide a protective market 
buffer for many of the work-force groups at risk of low wages. The classic example is social care work, which faces increasing labour demand in an ageing society and yet still allows entry to unqualified workers, thereby granting employers too much discretion in assigning a rate of pay to this form of skilled work, in which women are over-represented. As Figure 13.14 shows, the incidence of low pay remains considerably higher for women than for men and there is no sign of convergence in the cross-country shares of low wage employment.

A further cause of concern for the UK's problem of low-paid work is that the wage data cover only employees. An apparent rise across Europe in dubious or false forms of 'own account' self-employment (self-employed without employees) is associated with hiring practices found in a raft of sectors, notably construction, care, cleaning and security, as well as platform-economy firms (logistics, transport and information technology-enabled crowdwork). Thus there are major questions about the degree to which traditional sources of earnings data can capture the spectrum of income from employment for a growing share of Europe's working population. In 2015 there were around 22 million own-account self-employed in the EU compared with around 180 million employees (all workers aged 15-64); this is a small share compared with low- and middle-income countries (see ILO 2017), but is nevertheless of concern. While the share of self-employment in the total workforce has remained stable in Europe in recent decades,${ }^{20}$ there has been a rise in the proportion registered as without employees, particularly working part-time (Eurostat data). In the UK, the overall share has grown, as has the proportion defined as own-account self-employed, which has risen by around 70 per cent since 2001 , while the number of self-employed with employees has fallen (by circa 10 per cent up to 2016). We consider the ramifications of this issue in detail in the case study in section 6 .

\subsection{Persistent Long Working Hours for Men, Especially Fathers, and a Fragmented Pattern for Women}

As with all dimensions of labour market performance, the UK's pattern of sex segmentation offers the main clue to its relative standing compared with the rest of Europe. Taking all employed persons into consideration, the UK is not a long-hours country. It ranks twenty-second, with average working hours per week of 36.6. It is men in full-time jobs in the UK who work the long hours; the weekly average is 44.1, second only to Greece (the EU average is 42.3 hours). There are two further distinguishing characteristics of men's long hours in the UK. First, the trend there since 2007 is flat, while at EU level there has been a small decline and far more member states have experienced a fall rather than a rise in weekly working hours among male full-timers (13 versus five, considering only changes of more than 0.5 hours per week). Second, it is a trend that is notable for the participation of fathers. Lewis et al. (2008) found nearly half of UK fathers worked 46 hours or more per week, the highest share among 13 selected European countries in their study. Of further concern, the UK had the highest share of partnered fathers frequently working evenings and night shifts (37 per cent) and weekends ( 50 per cent) - in both cases the highest shares observed (Lewis et al. 2008). Working patterns of fathers in the UK are thus quite different from those observed in much of Europe. This may be partly a reflection of the more flexible working-time schedules allowed in the UK, but possibly also the need to top up family income by any means necessary. The problem is 
that it conspires against more equal sharing of care and other work in the home, and has long-term adverse health consequences.

At the other end of the working hours spectrum, the UK has a large share of women working part-time and their average working hours are not as long as in many other countries (19.6 hours per week compared with 23 or more in France, Belgium and Sweden; Eurostat 2016 data). As several studies show, there is considerable dispersion of working hours among female part-timers, reflecting the lack of regulation, including the absence of a right to minimum working hours. Employment rates of mothers in the UK are around the European average but, unlike Denmark, the Netherlands and Sweden, there is a significant difference in employment participation, and type of participation, by age of youngest child (OECD 2011). While households with dependent children (aged $0-15$ years) in several countries in Europe are characterised by a majority of couples both in full-time employment (Denmark, France, Portugal, Slovenia and Sweden, for example), the UK exhibits a very fragmented pattern (see also Lewis et al. 2008), such that there is no clear standard model or norm: 24 per cent adopt a sole-breadwinner pattern (one partner in full-time work), 31 per cent dual-earner (both partners work full-time) and 31 per cent follow a one-and-a-half earner model (male full-time, female part-time). ${ }^{21}$

Considering the family employment model, trends in Europe over the decade since 2004 reveal commonalities and differences (Figure 13.15). A common trend (21 of 23 countries) is the fall in single-breadwinner households (one partner works full-time, the other does not work), which was especially notable in Spain and Luxembourg. In the

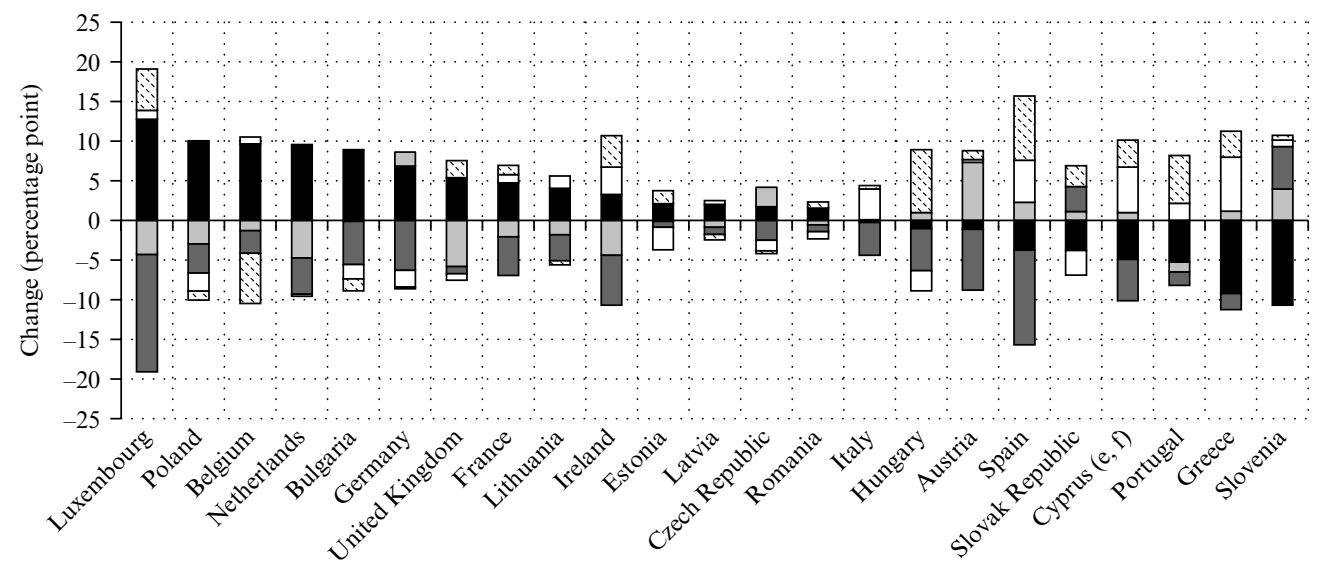

Both partners full-time $\square$ One partner full-time, one partner part-time $\square$ One partner full-time, one partner not working $\square$ Both partners not working 国 Other

Note: Percentage point change in the distribution of employment patterns in couples with at least one child aged $0-14$ years between 2004 and 2014.

Source: Adapted and copied from the OECD, accessed 23 March 2018 at http://www.oecd.org/els/family/ database.htm.

Figure 13.15 Changes in patterns of employment among couples with children, $U K$ and selected EU countries, 2004-14 
UK the fall was small, from 25 per cent to 24 per cent of all households, but nevertheless followed the convergent direction of change. Countries diverged concerning dual-earner households. Figure 13.15 shows that 14 countries experienced a rise in both partners working full-time - including the UK - but eight experienced a fall in this model. Similarly, ten European countries experienced a rise in the one-and-a-half model and nine a fall (including the UK).

Given the mixed trend in Europe, it is not possible to state that the UK has converged or diverged. Instead, a small share of households with working parents have swapped the one-and-a-half earning model for the dual full-time model. Detailed analysis suggests this reflects a variety of factors, including higher levels of education among mothers and improved public childcare (Connolly et al. 2016). However, there are obstacles to further progress towards a gender-egalitarian family model. The UK has resilient cultural views about the need for mothers to provide care for children of preschool age rather than for parents to share care (Baird and O'Brien 2015, cited in Connolly et al. 2016). Also, the UK lags behind other countries in policy reforms that might encourage a family employment model: it has a laissez-faire approach to working hours, its childcare provision is the most expensive in the EU, ${ }^{22}$ statutory maternity pay is very low and many public services are still organised around the assumption of one full-time breadwinner plus part-time carer. Therefore, UK policy reforms are still 'maternalist and minimalist' compared with other European countries (Connolly et al. 2016) and this will slow down a post-Brexit transformation to egalitarian sharing of work and care, as revealed by analyses of preferences among men and women in many European countries (see Müller et al. 2016). ${ }^{23}$

\section{CASE STUDY: UNIONS FIGHT AGAINST BOGUS SELF-EMPLOYMENT IN THE GIG ECONOMY}

After several years of popular concern about the human resource strategies of large firms in the gig economy, the years 2017 and 2018 for the UK saw several significant legal decisions and positive shifts in employer behaviour against exploitative use of false self-employment contracting instead of formal employment contracts. The issue is not new and nor is it the inevitable result of digital technologies. It has been associated with problems of precarious work in the construction industry for many decades (for example, Druker et al. 1996; Behling and Harvey 2015) and indeed has been the object of longstanding trade union campaigns in that industry against unscrupulous employers, led by the Union of Construction, Allied Trades and Technicians (UCATT). Nevertheless, with the rise of the gig economy, associated in particular with e-commerce, logistics/delivery firms and new business models of transport, the evidence of inappropriate employment relationships has escalated. This case study analyses the issue by first tracking what we know about patterns of self-employment at European level. It then presents two critical company cases in which unions and activists have successfully applied pressure to shift employers towards more ethical behaviour (Table 13.2).

The rising numbers of false self-employment is a European problem, not limited to the UK. Many countries are in fact worried that this form of employment is holding back the standard of living for a growing share of the working population. According to an illuminating Eurofound (2017) study, there are good reasons for concern. Compared with 
Table 13.2 Key evidence and events in two company cases, United Kingdom

\begin{tabular}{|c|c|c|c|c|}
\hline Company & Catalyst & Evidence of exploitation & $\begin{array}{l}\text { Counter- } \\
\text { movements }\end{array}$ & Result \\
\hline DPD & $\begin{array}{l}\text { Union protests } \\
\text { at Scotland } \\
\text { depots and } \\
\text { company } \\
\text { shamed } \\
\text { by media } \\
\text { revelation } \\
\text { of death of } \\
\text { a diabetic } \\
\text { driver fined } \\
\text { for taking } \\
\text { time off }\end{array}$ & $\begin{array}{l}\text { Drivers paid per delivery } \\
\text { but enjoy no rights } \\
\text { Drivers fined } £ 150 \text { for } \\
\text { daily absence } \\
\text { (including hospital } \\
\text { visits) } \\
\text { Restricted 'service } \\
\text { breaks' limits holiday } \\
\text { flexibility }\end{array}$ & $\begin{array}{l}\text { Widely publicised } \\
\text { union protest } \\
\text { against } \\
\text { imposed } \\
\text { contract } \\
\text { Massive media } \\
\text { coverage } \\
\text { of death of } \\
\text { driver with } \\
\text { diabetes who } \\
\text { was fearful of } \\
\text { taking time off }\end{array}$ & $\begin{array}{l}\text { DPD abolishes } \\
£ 150 \text { daily fine } \\
\text { for missing } \\
\text { work } \\
\text { DPD offers all } \\
6000 \text { drivers the } \\
\text { legal right to be } \\
\text { 'workers' (with } \\
\text { lower delivery } \\
\text { payment) }\end{array}$ \\
\hline Uber & $\begin{array}{l}\text { Employment } \\
\text { Tribunal } \\
\text { case brought } \\
\text { by two } \\
\text { ex-drivers }\end{array}$ & $\begin{array}{l}\text { Many examples of direct } \\
\text { control indicative of } \\
\text { a direct employment } \\
\text { relationship - for } \\
\text { example, Uber sets } \\
\text { fee and the route, } \\
\text { recruits drivers, } \\
\text { applies a performance/ } \\
\text { disciplinary code }\end{array}$ & $\begin{array}{l}\text { Initial support by } \\
\text { the union } \\
\text { GMB } \\
\text { The two plaintiffs } \\
\text { are members } \\
\text { of IWGB and } \\
\text { one co-founded } \\
\text { the branch of } \\
\text { private hire } \\
\text { drivers }\end{array}$ & $\begin{array}{l}\text { Drivers win } \\
\text { their legal case } \\
\text { to be treated as } \\
\text { 'workers' } \\
\text { Uber is appealing }\end{array}$ \\
\hline
\end{tabular}

the self-employed with employees, a higher share of self-employed without employees assume this status for lack of better alternatives and a higher share report financial vulnerability (measured by expected loss of income owing to illness). A more refined statistical cluster analysis finds that, while around half of Europe's self-employed report generally favourable levels of autonomy and opted to become self-employed out of choice, two groups labelled 'vulnerable' and 'concealed' account for one in four selfemployed with a high likelihood of precarious work, low income and limited discretion. Women are over-represented among the vulnerable category (owing to its prevalence in agriculture and domestic cleaning), while men are more likely to be found among 'concealed' forms of self-employment (in transport and construction, among other sectors) (Eurofound 2017, pp. 17-26). While around two-fifths of self-employed without employees fit in the cluster of stable own-account and another one in ten as employers, some one in five are 'vulnerable' and one in ten 'concealed', far higher than respective shares for self-employed with employees.

Turning to income, across Europe there is a clear relationship between being selfemployed and the level of real monthly net earnings (Figure 13.16). Those in the 'vulnerable' cluster report by far the lowest level of income and it is no accident that this is the category of self-employed in which women are over-represented. Figure 13.16 also shows there is a correlation between level of earnings and perceptions of being paid 


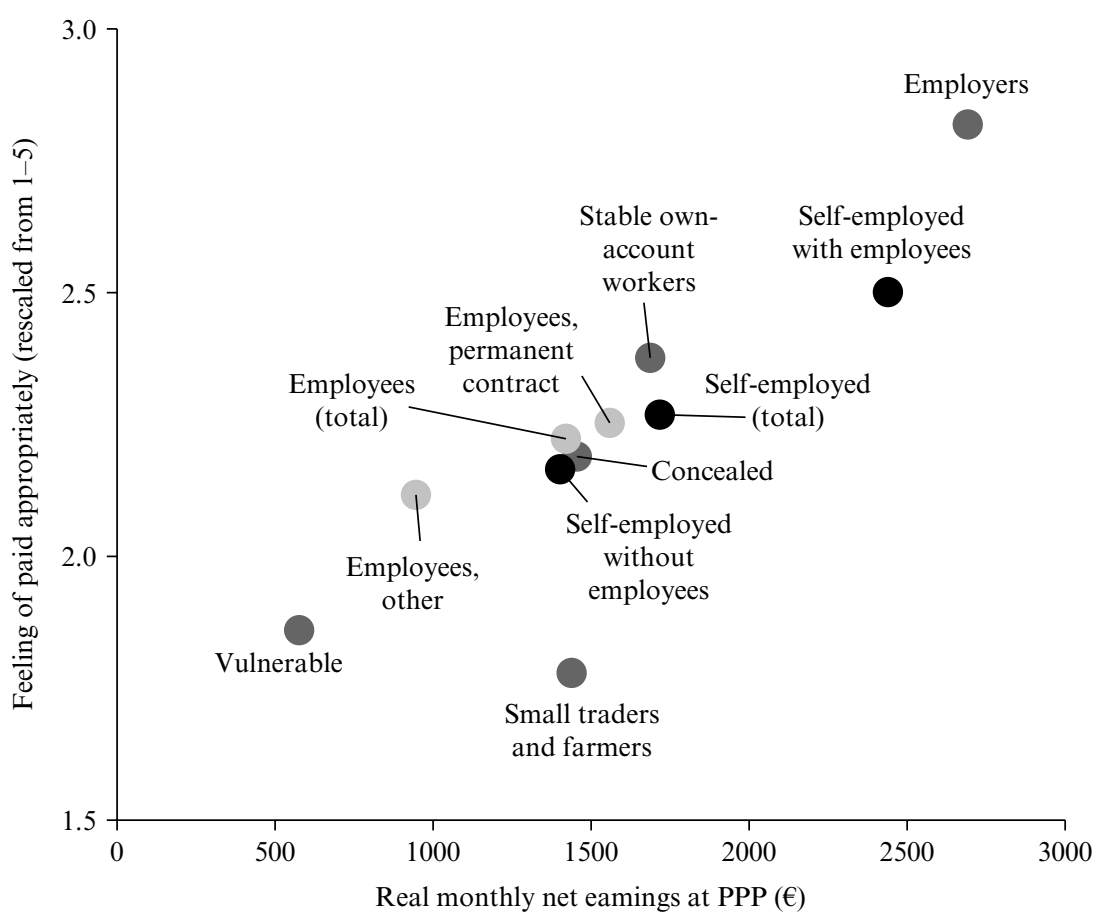

Note: $\quad \mathrm{PPP}=$ purchasing power parity.

Source: Eurofound (2017, fig. 23).

Figure 13.16 Real net earnings for employees and self-employed in UK and EU28 and perceptions of fair pay

appropriately. For the UK, national data show that weekly gross income for the total combined group of self-employed is significantly lower than for employees: Figure 13.17 suggests a modal level of income of around $£ 240$ a week for self-employed compared with around $£ 400$ for employees. The gap needs to be treated with caution, however, as the self-employed are likely to under-report their income (for tax reasons, for example). Differences by industry as well as number of hours worked may explain some of the earnings gap. However, even controlling for hours, the data show that compared with average earnings of male full-time employees, the full-time self-employed earned just 68 per cent (male) and 46 per cent (female). It is not surprising, therefore, to find that trade unions and civil society organisations have voiced their concerns about the increasingly substantial shift to self-employment, often on a bogus basis, for a growing share of entrants (and re-entrants) to the labour market. 


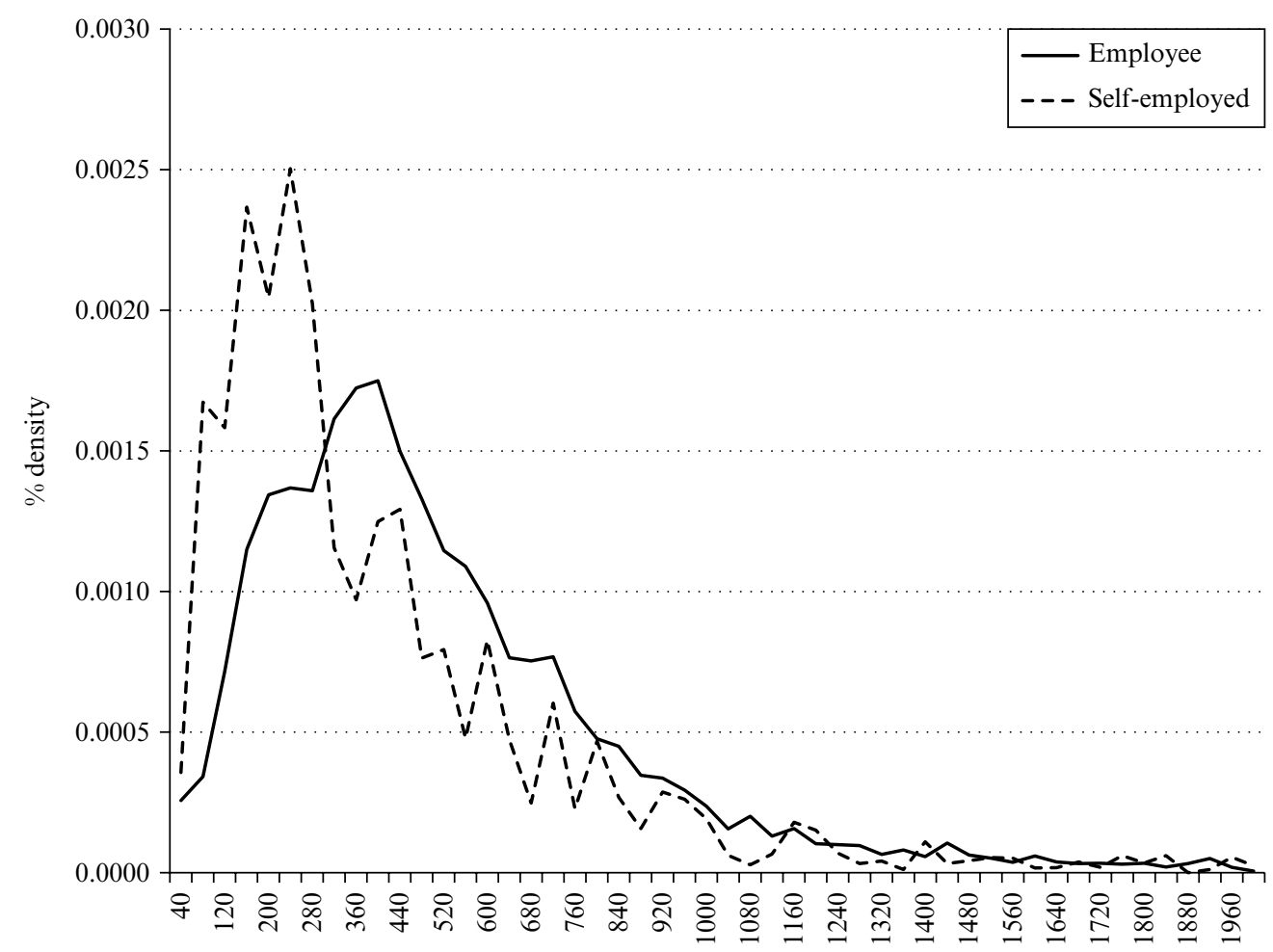

Gross weekly income

Note: Self-employment is reported as the main source of income and, like employees, can be part-time or full-time.

Source: Family Resources Survey data, Office for National Statistics.

Figure 13.17 Distribution of employee and self-employment income, UK, 2016

\subsection{Two Platform Companies Successfully Targeted by Trade Unions}

Like many other delivery companies, the global firm DPD has experienced accelerated growth in revenues and profits in recent years: 2016-17 saw a 12 per cent increase in parcel deliveries and an 8 per cent increase in spending. In 2017, DPD accounted for the second highest share of the courier parcel market by revenue with a 12 per cent market share (after Royal Mail, with 35 per cent). Despite the successful revenue flows, and again similar to other delivery firms, DPD nevertheless opted to set up its UK workforce of around 6000 drivers as self-employed.

Investigations have shown, however, that the company established a clear relationship of authority with its self-employed drivers, known as 'owner driver franchisees'. Drivers wear the company uniform, drive its vans and use DPD scanners. Also, according to evidence collected by the GMB (the main trade union for couriers in the private sector), 
as well as interviews quoted in the report by Labour MP Frank Field (Field and Forsey 2017), the drivers exercise no control over changes to their contracts (for example, in setting the fee per delivery), no control over what days or hours they work, no control over the routes for delivery, are not allowed to work for another company and can only take two non-consecutive, unpaid weeks off ('service breaks') per year. ${ }^{24}$ Drivers do not experience the flexibility and negotiating power of a self-employed worker, but neither do they have the basic rights of a directly employed worker. For example, in late 2017, DPD introduced unilateral changes to drivers' terms of work, involving reduced rates of pay per delivery and additional compulsory weekend working, which were introduced on a 'take it or leave it' basis; around 20 drivers refused to sign the new contracts and were dismissed. ${ }^{25}$ Managers refused to meet with officials of the GMB union, which organised driver walkouts and demonstrations across depots in Scotland in a coordinated one-day protest.

The events took a new turn in February 2018 following the death of one of DPD's drivers, who had worked for the company for 19 years. Newspapers revealed that the driver, aged 53 and with diabetes, had faced daily absence penalties of $£ 150$ (including a fine for seeing a doctor to treat eye damage) and so missed three appointments to treat kidney damage from his diabetes. ${ }^{26} \mathrm{He}$ collapsed while at work and subsequently died in hospital. Six weeks later, under massive trade union and media pressure, the company announced a new personnel strategy. It would offer its 'owner driver franchisees' the option of being treated as either a worker or to continue as self-employed, with the option subject to renewal each year. Under UK legislation, worker status brings a number of important rights: a minimum wage, sick pay, holiday pay, protection against unlawful deductions from wages and against unlawful discrimination, protection for whistleblowing and the right to a pension. While an important union achievement, there are nevertheless two downsides: drivers would be paid less per delivery if they opted for worker status and the new rights are only a sub-set of the full package of rights afforded to an employee, which would also grant protection against unfair dismissal, redundancy pay, right to flexible working, and maternity and paternity leave.

The second company case involved a legal challenge to the classification of drivers as self-employed, again backed by the GMB trade union. Two individuals who had worked as drivers for the taxi company Uber made a legal challenge, supported by GMB and on behalf of 19 Uber workers, to argue they were employed directly by Uber and did not work for themselves (Figure 13.18). The case had potentially substantial ramifications given both the size of the Uber workforce ( 40000 in the UK) and other related e-platform logistics companies. In its defence, Uber argued it was a technology firm and that the drivers were self-employed and could choose when and where they worked. The drivers argued that Uber exerted control: it sets the fee, it determines the route, it interviews and recruits drivers, it deactivates drivers whose performance ratings fall below a threshold ( 4.4 out of 5 for drivers who made more than 200 trips), it withholds information about where a customer wants to go until after they have been picked up, it requires drivers to accept trips, it handles complaints by the passenger about the driver and it reserves the right to change the driver's terms unilaterally. Moreover, the Tribunal case highlighted several instances in the company's own communications and documents where it referred to 'Uber drivers' and 'our drivers' (UKEAT 2017).

The drivers won the case to be treated as workers rather than self-employed (specifically with respect to minimum wage legislation, working time rules and employment rights 


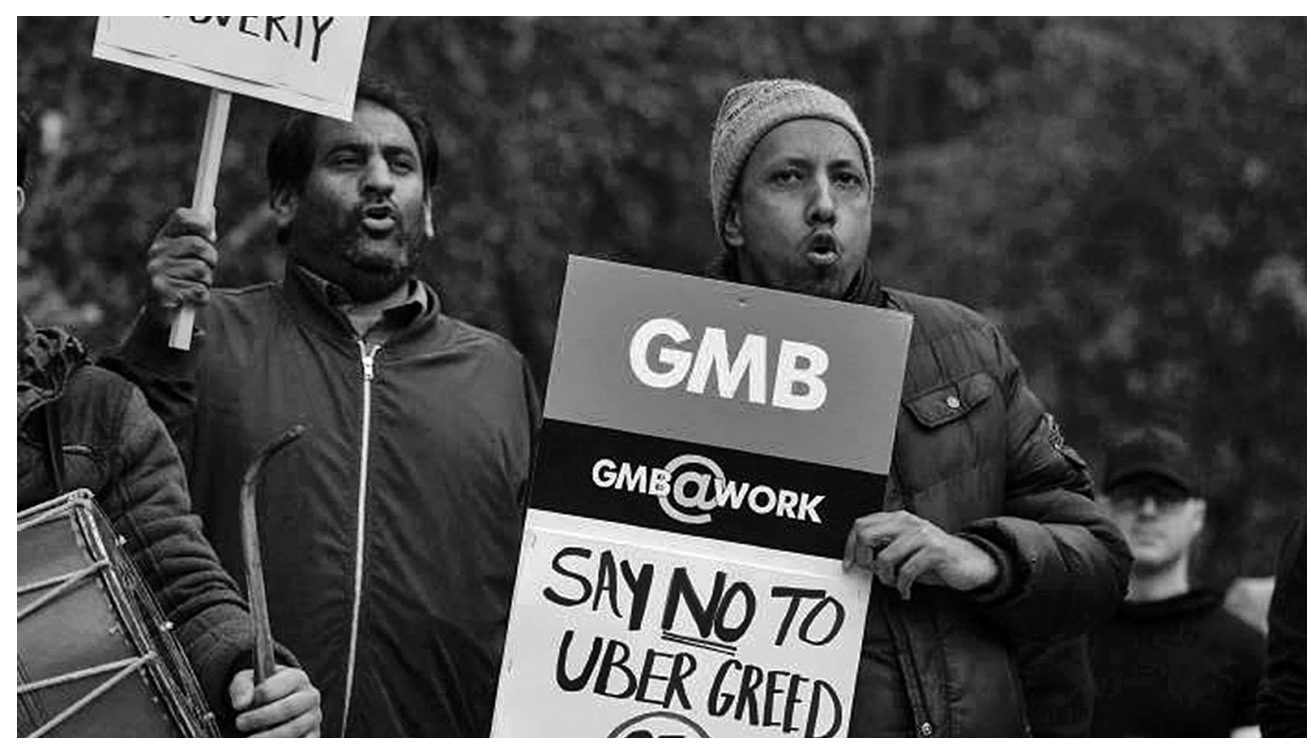

Source: Financial Times, 28 October 2016, accessed 23 March 2018 at https://www.ft.com/content/ a0bb02b2-9d0a-11e6-a6e4-8b8e77dd083a.

Figure 13.18 Uber drivers protest against a unilateral rise in the fee paid to the company in 2015 (from 20 per cent to 25 per cent).

legislation). The judges at the Employment Tribunal ruled that: 'The notion that Uber in London is a mosaic of 30,000 small businesses linked by a common "platform" is to our minds faintly ridiculous . . Drivers do not and cannot negotiate with passengers . . . They are offered and accept trips strictly on Uber's terms. ${ }^{27}$

The Tribunal concluded that the contract between Uber and its drivers was 'located in the field of dependent work relationships', such that the drivers were recruited to work 'as integral components' of Uber's business organisation; that is, not an arms-length business relationship (UKEAT 2017). Uber was allowed to appeal but lost again in September 2017. Importantly, the two claimants are members of a new, fast-growing independent trade union, the Independent Workers Union of Great Britain (IWGB); one of them chairs the union branch of private hire drivers. In a public statement, they affirmed the importance of the union's support:

In becoming part of the IWGB, we feel confident that vulnerable workers will never be offered up as collateral damage for someone else's battle. ... We couldn't be more proud of our membership and association with the IWGB - it is a true home for independent workers and has risen to become the undoubted de facto trade union leader for the so-called gig economy. ${ }^{28}$

Since the ruling, Uber has had to answer questions to government about its intentions to introduce limits to driver hours. The case will be reviewed again at the Court of Appeal in 2019 .

As it stands, the ruling has great symbolic significance and yet, owing to the way UK labour law operates, is in practice quite limited. First, the ruling is not binding on the way 
Uber treats its work force, only the plaintiffs of the case. Second, it may or may not mean that bogus self-employment in other delivery firms will be re-classified since each legal case is considered on its own merits. Third, the case law may be superseded by subsequent decisions. What is required is better legislation that stops employers - specifically those self-branded as platform companies - from exploiting their work force by denying them their basic rights.

\section{CONCLUSIONS}

Questions of social and economic convergence in Europe are complicated by the multiple and contradictory convergence pressures associated with Europeanisation - including free-market pressures, social or institutional, pressures, and labour market pressures - as well as the impossibility of separating out the effects of other (possibly stronger) pressures associated with globalisation (especially low-cost competition with low- and middle-income countries), diffusion of e-platform business models and financialisation. Added to this, each member state of the EU responds to convergence pressures in different ways, and processes and outcomes are refracted by the distinctive strategies and capacities of social actors, a process labelled 'contingent convergence' (Hay 2010). Thus, while this chapter has presented various headline indicators of social and economic performance with a view to assessing the UK's position against its European neighbours, it does not aspire to arrive at a summary, unidimensional conclusion regarding overall convergence or divergence between the UK and a European average.

With regard to economic performance, assessment of levels of GDP per capita and debt across Europe signal divergence rather than convergence, with the UK performing below its past record, particularly since the economic crisis. On social performance, the UK record is marred by high levels of inequality - second highest in the EU - and a growing problem of in-work poverty which has offset a welcome decline in poverty among pensioners. Across Europe, the pattern is heterogeneous, reflecting diverse welfare state models and commitments to expenditures. The UK has a mixed record as a 'residual welfare state' and the goal of social development is likely to suffer further due to the government's persistent determination to cut government expenditures on education, health and social protection spending, despite strong resistance and campaigns by public sector employers and trade unions. Finally, the UK performs very well as a jobs-generating machine but less so in delivering satisfactory work for all, especially for women. The problem is in part a reflection of its weak mechanisms and structures for social dialogue, so that gains are typically ad hoc and not widely diffused, as we are witnessing with regard to campaigns against bogus self-employment in the logistics and transport industries. However, it is also a demand-side problem, related to issues not considered in this chapter, involving the financialisation of the UK economy (with limited protections against takeovers, penetration by short-termist private equity funds and dominance of the shareholder primacy model) and the weakness of its sustained capacity for innovation and research and development.

So, what will a future outside the EU look like? The UK had already distanced itself from the institutional principle, prevalent in most of the EU, that social dialogue is a fundamental element of social development. Neither employers nor workers are well 
organised, and with the odd exception - for example, the Low Pay Commission, which sets the statutory minimum wage - employers and unions do not play a substantive role in designing and shaping economic, social or labour market policy. Once outside the EU, it is even more unlikely that the UK would enjoy a renaissance of its industrial relations institutions, which may explain the anti-Brexit positions in 2016 of the two peak bodies, the Confederation of British Industry (CBI) and the Trades Union Congress (TUC). What about future imitation of EU directives? Workers in the UK have benefited from enhanced job quality and equality of treatment resulting from employment-related EU directives, despite the UK's legally negotiated opt-outs and problems of employer compliance. However, it is difficult to predict how the UK will respond to future directives and other measures of soft coordination. The scope of UK choice may be constrained by the shape of the EU-UK trade deal (assuming the EU will wish to act against UK competitive advantage via social dumping) and there will also presumably be sustained political pressures to keep up with measures of social progress on the other side of the Channel. However, a political revolt against EU regulations is likely and will be associated with a significant bolstering of the neoliberal economics discourse that is firmly entrenched in UK business and politics and which, in the present international climate, will enjoy strong support from the United States. Trade unions and employer bodies are effectively locked out of the current highly risky path of transformation, despite their primary interests in protecting workers and business, respectively, both vital to the stability and prosperity of the country. Brexit will be a disaster for the UK economy and it is very likely it will impede our record of social, environmental and cultural development as the country establishes an increasingly hostile context both for foreigners aspiring to work and raise families and for businesses seeking to pursue socially responsible corporate success. Thus, while the EU faces important challenges about how to guide member states towards greater convergence (see Eurofound 2018), the UK is already drifting away and will find it increasingly difficult to prop up its commitment to social and environmental goals as the economy is buffeted by adverse shocks caused by a worsening of trade, reduced labour migration, falling business investment and exit of multinational companies.

\section{NOTES}

1. Established in 1992, the single market reflected a strengthened ambition for economic integration and was outlined in the Single European Act signed by 12 member states in 1987. It is complemented by the Maastricht Treaty (Treaty on European Union), signed in 1992, that established the three-pillar structure of the EU and paved the way for the introduction of the euro.

2. See European Commission (2017).

3. See, for example, Hartzén et al. (2008) on the varied forms of application of the Transfer of Undertakings Directive.

4. All data in this subsection are sourced from the IMF World Economic Outlook database.

5. During 2008-15, annual change in GDP per capita for the EU28 averaged 0.7 per cent, compared with just 0.1 per cent for the UK. This is particularly surprising given the sustained collapse in GDP per capita in Greece, Cyprus, Italy and Spain, which significantly dampened the overall EU28 average.

6. The case of Ireland is very interesting. It posted 26 per cent growth in GDP in 2015. This is said to have resulted from a boom in both net exports and depreciation of assets, largely caused by relocation of productive assets to Ireland (Irish Times, irishtimes.com, 15 July 2016).

7. Data from Eurostat, 'General government gross debt', available at http://ec.europa.eu/eurostat/tgm/down load.do?tab=table\&plugin=1\&language=en\&pcode=tipsgo20 (accessed 23 March 2018). The fourth quarter 2002 is the earliest data with information for all 28 member states. 
8. Household debt refers to the aggregation of all outstanding loans, including mortgages, credit card debt, bank overdrafts, personal loans, car loans and student loans.

9. Debt and incomes are reported for the median points of each quintile and no account is taken of differences in household composition (ONS 2016).

10. Note the data on poverty rates use income levels after housing costs.

11. The estimate uses the government's official measure of absolute poverty after housing costs are deducted from household income.

12. Data extracted from OECD (2017), accessed 25 January 2018 at http://www.oecd-ilibrary.org/docserver/ download/4217001e.pdf?expires $=1516876754 \& \mathrm{id}=\mathrm{id} \&$ accname $=$ guest\&checksum=AEA76A640B72294 B3B1202577B171060.

13. For example, the largest falls in real expenditures per capita during 2009-15 were recorded in Greece and Ireland, located at opposite ends of the spectrum of spending as a share of GDP (OECD 2017, fig 2.29 and 2.31).

14. Data extracted from various pages of the Office for National Statistics data resource web pages, accessed at ons.org.uk/ (accessed 23 March 2018).

15. A listing of the activities of the National Association of Head Teachers can be found at http://www.naht. org.uk/welcome/news-and-media/campaigns/school-funding-in-crisis/ (accessed 23 March 2018).

16. HM Treasury data on real terms government expenditures by function.

17. See https://schoolcuts.org.uk/\#!// (accessed 23 March 2018).

18. Data for France missing. Population refers to persons aged 20-64 years.

19. All unemployment data refer to the third quarter of 2017, sourced from Eurostat.

20. The net effect is deceptive as the stability is caused largely by a decline in the agricultural sector as a source of employment, where the incidence of self-employment is relatively high.

21. Data from the OECD database on the labour market position of families, accessed 23 March 2018 at http://www.oecd.org/els/family/database.htm\#labour_market.

22. OECD data estimate full-time childcare fees for two children aged 2 and 3 years old as a percentage of average full-time earnings: the highest is 64 per cent in England, compared with 20 per cent in France, 23 per cent in Spain and 7 per cent in Sweden.

23. Müller et al.'s data analysis (2016, table A1) suggests that preferences are increasingly shifting across Europe (albeit to different degrees by country) towards a 'two times three-quarter employment model'.

24. See information detailed on the GMB website, http://www.gmb.org.uk/dpd-drivers-protest (accessed 23 March 2018). In Field and Forsey (2017, p. 7), one DPD driver is quoted as saying, 'we must provide a full day's service at the weekend and they will pick what day we work, it could be Saturday or Sunday ... we have been told [that] if we refuse to work one of these days on three occasions then we will be terminated from our contracts'.

25. http://www.gmb.org.uk/newsroom/dhl-accounts-ashamed (accessed 23 March 2018).

26. https://www.theguardian.com/business/2018/feb/05/courier-who-was-fined-for-day-off-to-see-doctor-diesfrom-diabetes (accessed 23 March 2018).

27. Cited in the Guardian, 28 October 2016, accessed 23 March 2018 at https://www.theguardian.com/ technology/2016/oct/28/uber-uk-tribunal-self-employed-status.

28. http://www.uphd.org/statement-from-uber-claimants-james-farrar-and-yaseen-aslam/ (accessed 23 March 2018).

\section{REFERENCES}

Almond, P. (2017), 'The persistence of, and challenges to, societal effects in the context of global competition', in D. Grimshaw, C. Fagan, G. Hebson and I. Tavora (eds), Making Work More Equal: A New Labour Market Segmentation Approach, Manchester University Press, pp. 52-69. Amable, B. (2003), The Diversity of Modern Capitalism, Oxford: Oxford University Press.

Baird, M. and M. O'Brien (2015), 'Dynamics of parental leave in anglophone countries: the paradox of state expansion in the liberal welfare regime', Community, Work \& Family, 18 (2), 198-217.

Behling, F. and M. Harvey (2015), 'The evolution of false self-employment in the British construction industry: a neo-Polanyian account of labour market formation', Work, Employment and Society, 29 (6), 969-88.

Belfield, C., C. Crawford and L. Sibieta (2017), 'Long-run comparisons of spending per pupil across different stages of education', IFS Report R126, Institute for Fiscal Studies, London. 
Bettio, F. and S. Sansonetti (eds) (2015), 'Visions for gender equality', Report for the European Commission, Directorate-General for Justice and Consumers.

Bisello, M. and M. Mascherini (2017), 'The gender employment gap: costs and policy responses', Intereconomics, 52 (1), 24-27.

Bosch, G., S. Lehndorff and J. Rubery (eds) (2009), European Employment Models in Flux: A Comparison of Institutional Change in Nine European Countries, Basingstoke: Palgrave Macmillan.

Clauwaert, S. and Schömann, I. (2012), 'The crisis and national labour law reforms: a mapping exercise', European Labour Law Journal, 3 (1), 54-69.

Connolly, S., M. Aldrich, M. O’Brien, S. Speight and E. Poole (2016), 'Britain's slow movement to a gender egalitarian equilibrium: parents and employment in the UK 2001-13', Work, Employment and Society, 30 (5), 838-57.

Cribb, J., A. Hood, R. Joyce and A. Kellier (2017), 'Living standards, poverty and inequality in the United Kingdom: 2017', Institute for Fiscal Studies, London.

Crouch, C. (2017), 'Neoliberalism and social democracy', in B. Jones and M. O'Donnell (eds), Alternatives to Neoliberalism: Towards Equality and Democracy, Bristol: Policy Press, pp. 193-208.

Druker, J., G. White, A. Hegewisch and L. Mayne (1996), 'Between hard and soft HRM: human resource management in the construction industry', Construction Management \& Economics, 14 (5), 405-16.

Emmerson, C., P. Johnson and I. Mitchell (2016), 'The EU Single Market: the value of membership versus access to the EU', Institute for Fiscal Studies, London, accessed 23 March 2018 at https://www.ifs.org.uk/ uploads/publications/comms/R119\%20- $\% 20 \mathrm{The} \% 20 \mathrm{EU} \% 20$ Single $\% 20$ market $\% 20-20$ Final.pdf.

Esping-Andersen, G. (1990), The Three Worlds of Welfare Capitalism, Oxford: Polity, chs 6 and 8.

Eurofound (2017), Exploring Self-employment in the European Union, Luxembourg: Publications Office of the European Union.

Eurofound (2018), 'Upward convergence in the EU: concepts, measurements and indicators', research report, Publications Office of the European Union, Luxembourg.

European Commission (2017), 'Establishing a European Pillar of Social Rights', Communication from the Commission, SWD(2017) 201 final.

Field, F. and A. Forsey (2017), 'A new contract for the "gig economy", report, accessed 23 March 2018 at http://www.frankfield.co.uk/upload/docs/A $\% 20$ new $\% 20$ contract $\% 20$ for $\% 20$ the $\% 20 \% 27$ gig $\% 20$ economy $\% 27$.pdf.

Freeman, R.B. (ed.) (1994), Working under Different Rules, New York: Russell Sage Foundation.

Gill, S. (1997), 'Finance, production and panopticism: inequality, risk and resistance in an era of disciplinary neoliberalism', in S. Gill (ed.), Globalisation, Democratisation and Multilateralism, London: Macmillan, pp. 51-75.

Goergen, M., N. O’Sullivan and G. Wood (2014), 'The consequences of private equity acquisitions for employees: new evidence on the impact on wages, employment and productivity', Human Resource Management Journal, 24 (2), 145-58.

Grimshaw, D. (2015), 'Britain's social model: rapid descent from "liberal collectivism" to a "market society", in D. Vaughan-Whitehead (ed.), The European Social Model in Times of Economic Crisis and Austerity Policies, Geneva: ILO and Cheltenham, UK and Northampton, MA, USA: Edward Elgar.

Grimshaw, D. and M. Johnson (2018), 'Inequality at work in the UK: how perforated industrial relations worsen inequalities and hold back progress on equalities', in D. Vaughan-Whitehead (ed.), Inequalities and the World of Work: What Role for Industrial Relations and Social Dialogue?, EC/ILO conference volume.

Grimshaw, D. and A. Rafferty (2016), 'How have middle-income households fared in unequal Britain? A focus on work and employment trends', in D. Vaughan-Whitehead (ed.), Europe's Disappearing Middle Class: Evidence from the World of Work, Cheltenham, UK and Northampton, MA, USA: Edward Elgar and Geneva: ILO, pp. 586-632.

Hall, P.A. and D.W. Soskice (eds) (2001), Varieties of Capitalism: The Institutional Foundations of Comparative Advantage, Oxford: Oxford University Press.

Harari, D. (2017), 'Household debt: statistics and impact on the economy', House of Commons Library Briefing Paper No. 7584, London. 
Hartzén, A.C., N. Hös, F.A. Lecomte, C. Marzo, B. Mestre, H. Olbrich, et al. (2008), 'The right of the employee to refuse to be transferred: a comparative and theoretical analysis', LAW Working Paper, European University Institute, Florence.

Hay, C. (2000), 'Contemporary capitalism, globalization, regionalization and the persistence of national variation', Review of International Studies, 26 (4), 509-31.

Hay, C. (2010), 'Common trajectories, variable paces, divergent outcomes? Models of European capitalism under conditions of complex economic interdependence', Review of International Political Economy, 11 (2), 231-62.

Hay, C. and B. Rosamond (2002), 'Globalization, European integration and the discursive construction of economic imperatives', Journal of European Public Policy, 9 (2), 147-67.

Hermann, C. and J. Flecker (eds) (2013), Privatization of Public Services: Impacts for Employment, Working Conditions, and Service Quality in Europe, London: Routledge.

Heyes, J. and P. Lewis (2014), 'Employment protection under fire: labour market deregulation and employment in the European Union', Economic and Industrial Democracy, 35 (4), 587-607.

Heyes, J., M. Tomlinson and A. Whitworth (2017), 'Underemployment and well-being in the United Kingdom before and after the Great Recession', Work, Employment and Society, 31 (1), 71-89.

Hood, A. and T. Waters (2017), 'Living standards, poverty and inequality in the United Kingdom: 2017-18 to 2020-21', Institute for Fiscal Studies, London.

Hutton, W. (1996), The State We're In, London: Random House.

International Labour Organization (ILO) (2016), 'Building a social pillar for European convergence', ILO, Geneva.

International Labour Organization (ILO) (2018), World Employment and Social Outcomes: Trends 2018, Geneva: ILO.

Johnston, A. and A. Regan (2016), 'European monetary integration and the incompatibility of national varieties of capitalism', Journal of Common Market Studies, 54 (2), 318-36.

Karamessini, M. (2014), 'Greece as an international test-case: economic adjustment through a Troika/state-induced depression and social catastrophe', in S. Lehndorff (ed.), Divisive Integration: The Triumph of Failed Ideas in Europe - Revisited, Brussels: ETUI, pp. 155-82.

Kitschelt, H., P. Lange, G. Marks and J.D. Stephens (1999), 'Convergence and divergence in advanced capitalist democracies', in H. Kitschelt (ed.), Continuity and Change in Contemporary Capitalism, Cambridge: Cambridge University Press, pp. 429-60.

Kristensen, P.H. and K. Lilja (eds) (2011), Nordic Capitalisms and Globalization: New Forms of Economic Organization and Welfare Institutions, Oxford: Oxford University Press.

Lewis, J. (1992), 'Gender and the development of welfare regimes', Journal of European Social Policy, 2 (3), 159-73.

Lewis, J., M. Campbell and C. Huerta (2008), 'Patterns of paid and unpaid work in Western Europe: gender, commodification, preferences and the implications for policy', Journal of European Social Policy, 18 (1), 21-37.

Müller, K. U., Neumann, M. and Wrohlich, K. (2016), 'The family working time model: toward more gender equality in work and care', DIW Berlin Discussion Paper No. 1603, German Institute for Economic Research, Berlin.

New Policy Institute (NPI) (2017), 'Young adults and the minimum wage: the case for lowering age eligibility', New Policy Institute Report for Unison, Supplementary evidence to the Low Pay Commission, accessed 11 January 2018 at https://www.unison.org.uk/content/uploads/2017/07/ Supplementary-evidence-2017-NPI-report-on-Young-Adults-and-the-Minimum-Wage.pdf.

Office for National Statistics (ONS) (2016), 'Household debt inequalities', accessed 23 March 2018 at https://www.ons.gov.uk/peoplepopulationandcommunity/personalandhouseholdfinances/debt/ articles/householddebtinequalities/2016-04-04.

Organisation for Economic Co-operation and Development (OECD) (2011), Doing Better for Families, Paris: OECD.

Organisation for Economic Co-operation and Development (OECD) (2016), Science, Technology and Innovation Outlook, Paris: OECD.

Organisation for Economic Co-operation and Development (OECD) (2017), Government at a Glance, Paris: OECD. 
Perrons, D., N. Lacey, A. Phillips, S. Wearing, S. Ashtiany, S., A. Biressi, et al. (2016), 'Confronting gender inequality: findings from the LSE commission on gender, inequality and power', accessed 23 March 2018 at http://eprints.lse.ac.uk/66802/1/Confronting-Inequality.pdf.

Rubery, J., A. Keizer and D. Grimshaw (2016), 'Flexibility bites back: the multiple and hidden costs of flexible employment policies', Human Resource Management Journal, 26 (3), 235-51.

Rubery, J., M. Smith, C. Fagan and D. Grimshaw (1998), Women and European Employment. London: Routledge.

Salvatori, A. (2018), 'The anatomy of job polarisation in the UK', Journal for Labour Market Research, 52 (1), accessed 16 January 2019 at https://doi.org/10.1186/s12651-018-0242-z.

Schmitter, P.C. (1997), 'The emerging Europolity and its impact upon national systems of production', in J. R. Hollingsworth and R. Boyer (eds), Contemporary Capitalism: the Embeddedness of Institutions, Cambridge: Cambridge University Press, pp. 395-430.

Solow, R. (1956), 'A contribution to the theory of economic growth', Quarterly Journal of Economics, 70 (1), 65-94.

Stier, H., N. Lewin-Epstein and M. Braun (2001), 'Welfare regimes, family-supportive policies, and women's employment along the life-course', American Journal of Sociology, 106 (6), 1731-60.

Taylor-Gooby, P. (ed.) (2016), Choice and Public Policy: the Limits to Welfare Markets, Basingstoke: Palgrave Macmillan.

United Kingdom Commission for Employment and Skills (UKCES) (2012), 'National Employer Skills Survey', UKCES, London.

United Kingdom Employment Appeal Tribunal (UKEAT) (2017), 'Uber B.V. and others versus Mr. Aslam and others', Transcript of Employment Appeal Tribunal, Appeal No. UKEAT/0056/17/DA, accessed 23 March 2018 at https://assets.publishing.service.gov.uk/ media/5a046b06e5274a0ee5a1f171/Uber_B.V._and_Others_V_Mr_Y_Aslam_and_Others_UK EAT_0056_17_DA.pdf.

Vaughan-Whitehead, D. (ed.) (2013), Public Sector Shock: The Impact of Policy Retrenchment in Europe, Cheltenham, UK and Northampton, MA, USA: Edward Elgar and Geneva: ILO.

Wahrendorf, M. and Chandola, T. (2016), 'A life course perspective on work stress and health', in J. Siegrist and M. Wahrendorf (eds), Work Stress and Health in a Globalized Economy, Cham: Springer International, pp. 43-66.

Whitley, R. (1999), Divergent Capitalisms: The Social Structuring and Change of Business Systems, Oxford: Oxford University Press.

Zhou, H., R. Dekker and A. Kleinknecht (2011), 'Flexible labor and innovation performance: evidence from longitudinal firm-level data', Industrial and Corporate Change, 20 (3), 941-68. 